\title{
Description and evolution of wood anatomical characters in the ebony wood genus Diospyros and its close relatives (Ebenaceae): a first step towards combatting illegal logging
}

\author{
Mehrdad Jahanbanifard ${ }^{1,2, *}$, Vicky Beckers ${ }^{1}$, Gerald Koch ${ }^{3}$, Hans Beeckman ${ }^{4}$, \\ Barbara Gravendeel $^{1,5}{ }^{1}$, , Fons Verbeek ${ }^{2}$, Pieter Baas ${ }^{1}$, Carlijn Priester ${ }^{7}$, and \\ Frederic Lens ${ }^{1}$ \\ ${ }^{1}$ Naturalis Biodiversity Center, Darwinweg 2, 2333 CR Leiden, The Netherlands \\ ${ }^{2}$ Section Imaging and Bioinformatics, Leiden Institute of Advanced Computer Science (LIACS), Leiden \\ University, Niels Bohrweg 1, 2333 CA Leiden, The Netherlands \\ 3Thünen Institute of Wood Research, 21031 Hamburg, Germany \\ 4Wood Biology Service, Royal Museum for Central Africa, 3080 Tervuren, Belgium \\ 5Institute of Biology Leiden, Leiden University, Sylviusweg 72, 2333 BE Leiden, The Netherlands \\ ${ }^{6}$ Institute for Water and Wetland Research, Radboud University, Heyendaalsweg 135, 6500 GL, Nijmegen, \\ The Netherlands \\ 7Amsterdam University of Applied Sciences, Weesperzijde 19o, 1097 DZ Amsterdam, The Netherlands \\ ${ }^{*}$ Corresponding author; email: mehrdad.jahanbanifard@naturalis.nl \\ Accepted for publication: 10 September 2020
}

\section{ABSTRACT}

The typical black coloured ebony wood (Diospyros, Ebenaceae) is desired as a commercial timber because of its durable and aesthetic properties. Surprisingly, a comprehensive wood anatomical overview of the genus is lacking, making it impossible to fully grasp the diversity in microscopic anatomy and to distinguish between CITES protected species native to Madagascar and the rest. We present the largest microscopic wood anatomical reference database for ebony woods and reconstruct evolutionary patterns in the microscopic wood anatomy within the family level using an earlier generated molecular phylogeny. Wood samples from 246 Diospyros species are described based on standardised light microscope observations. For the ancestral state reconstruction, we selected eight wood anatomical characters from 88 Ebenaceae species (including 29 Malagasy Diospyros species) that were included in the most recently reconstructed family phylogeny. Within Diospyros, the localisation of prismatic crystals (either in axial parenchyma or in rays) shows the highest phylogenetic value and appears to have a biogeographical signal. The molecular defined subclade Diospyros clade IX can be clearly distinguished from other ebony woods by its storied structure. Across Ebenaceae, Lissocarpa is distinguishable from the remaining genera by the combined presence of scalariform 
and simple vessel perforation plates, and Royena typically has silica bodies instead of prismatic crystals. The local deposition of prismatic crystals and the presence of storied structure allow identifying ebony wood species at the subgeneric level, but species-level identification is not possible. In an attempt to improve the identification accuracy of the CITES protected Malagasy woods, we applied computer vision algorithms based on microscopic images from our reference database (microscopic slides from ca. 1000 Diospyros specimens) and performed chemical profiling based on DART TOFMS.

Keywords: Ancestral state reconstruction; CITES; timber identification; wildlife trade; wood anatomy.

\section{INTRODUCTION}

Globally, it is estimated that $10-30 \%$ of the timber trade is illegally harvested (Irwin 2019; Nellemann 2012). If we only consider timber trade in tropical forests, an estimation between $30-90 \%$ is more likely (Hirschberger 2008; Hoare 2015). Mixing legally and illegally logged wood makes it challenging for customs officers to assess the validity of the official documents that are linked to a particular shipment (McClure et al. 2015). Efficient and accurate identification tools are therefore critical for species identification and origin assessment of traded timbers and will likely contribute to protecting forests and their associated biodiversity (Dormontt et al. 2015; Koch \& Haag 2015; Tacconi et al. 2016). To this end, these tools must be embedded in law enforcement, especially in developing countries that produce the majority of tropical timbers (Dormontt et al. 2015).

Ebony wood belongs to the genus Diospyros, which is the largest genus in the mediumsized pantropical family Ebenaceae (Samuel et al. 2019). The genus comprises more than 800 species (ca. 720 described) of trees and shrubs (Linan et al. 2019). The inner portion of a mature trunk, referred to as heartwood, of a typical ebony tree is coloured dark brown to jet black and is durable, which makes it highly desirable for the production of amongst others high valued musical instruments, ornaments, and furniture (Belemtougri et al. 2006). The typical black colour of ebony heartwood is the result of dark-coloured organic deposits in the vessels, parenchyma cells, and fibres during heartwood formation. This dark or marbled coloured heartwood is documented in about 40 Diospyros species (Gottwald 1984), but there must be many more ebony wood species with black heartwood, especially amongst the tree species.

The genus Diospyros is in desperate need of an updated taxonomic revision due to overlapping species descriptions (Van Den Brink 1936; Wallnöfer 2001, 2006, 2008, 2009, 2010, 2012, 2013, 2014, 2016, 2017, 2018, 2019; White \& Verdcourt 1996). The taxonomic "chaos" for the Malagasy Diospyros species is particularly serious: 91 species have been described in Madagascar, of which 88 are endemic to the island (Madagascar Catalogue 2019), but it is estimated that there are about 200 Malagasy endemics in total, including ca. 5 o undescribed tree species with potential black heartwood. Since 2013, all the Malagasy species 
have been listed on CITES Appendix II due to rapid decline in the wild as a result of extensive logging during a governmental crisis in 2009, meaning that nowadays Malagasy ebony woods can only be imported or exported with a CITES permit (Mason 2019; UNODC 2016). To implement CITES legislation, species identification of Malagasy Diospyros species is of utmost importance, especially because the hardest and most precious black wood samples from Madagascar are known to grow in the north-eastern part of the island, a region with many undescribed Diospyros species (Porter P. Lowry II, pers. comm.). The complex taxonomic status of Diospyros in Madagascar is currently under study by an ongoing EUfunded consortium that is revising all known Malagasy species and describing many new ones (Schatz \& Lowry 2018).

When zooming out of the challenging taxonomy in Malagasy Diospyros, also the delimitation of genera that have been associated with Diospyros has been controversial for many decades. According to the latest molecular phylogeny of the family (Samuel et al. 2019), four genera are currently recognised within Ebenaceae: Lissocarpa, which is sister to the rest of the family, the closely related genera Euclea and Royena, and the expanded genus Diospyros (including the former genera Cargillia, Gunisanthus, Maba, Macreightia and Tetraclis). Molecular phylogenies show support for 11 subclades within Diospyros (subclades I-XI in (Duangjai et al. 2009), but resolution amongst these subclades remains rather low.

There has been considerable debate whether or not anatomy would be a good method to identify Diospyros to species level (Morton 1994; Wallnöfer 20o1). While most studies agree that wood identification at the species level is often not possible (Gasson 2011), wood anatomy remains the most frequently used method for timber identification, as highlighted in the recent UN report on the Best Practice Guide on Forensic Timber Identification (UNODC 2016) and guidelines of the Global Timber Tracking Network (GTTN) (Schmitz et al. 2019). However, wood anatomical descriptions for Diospyros are rather scarce and scattered in the literature (Kanehira 1921, 1924; Janssonius \& Moll 1926; Yao 1932; Brown \& Panshin 1940; Record 1943; Metcalfe \& Chalk 1950; Panshin \& Zeeuw 1970; Normand \& Paquis 1976; Détienne \& Jacquet 1983; Gregory 1994; Wickremasinghe \& Heart 20o6; Grubben 2004; Wheeler 2011; Ravaomanalina et al. 2017). The only studies that provide descriptions of many more species are the unpublished PhD theses of Morton (1994) who studied 148 wood samples from 93 species, based on the sections and observations by Helmut Gottwald (Thünen Institute, Hamburg, Germany), and the one by Frederic Lens (2005); 22 species).

Our first objective was to compile the largest wood anatomical reference dataset for Ebenaceae in the world, including complete descriptions of 256 species (including 246 Diospyros species, four Euclea species, two Lissocarpa species and four Royena species) based on samples from Naturalis Biodiversity Center (Leiden, The Netherlands), the Royal Museum for Central Africa (Tervuren wood collection, Tervuren, Belgium) and the Thünen Institute (Hamburg, Germany). Our second objective was to assess the value of wood anatomy for identification purposes at the subgeneric and species level, especially with respect to distinguishing CITES protected species from the non-protected species. As a third objective, we confronted our wood anatomical descriptions with molecular phylogeny at the family 
level to investigate evolutionary patterns for selected features via ancestral state reconstruction analyses. This paper represents the first part of our project, where the general objective was to develop a species identification tool for ebony woods based on microscopic wood anatomical traits (this study), image recognition, and chemical profiling with DART-TOFMS (Direct Analysis in Real Time-Time Of Flight Mass Spectrometry) (follow-up studies).

\section{MATERIALS AND METHODS}

\section{Sampling strategy}

Wood sections of 246 Diospyros species, four Euclea species (E. divinorum, E. lanceolate, E. natalensis and E. schimperia), four Royena species (R. glabra, R. lucida, R. lycioides, and R. pallens), and two Lissocarpa species (L. bentami and L. guianensis) were available for this study (see Table $A_{1}$ in the Appendix). Mature wood samples (stem diameters of at least $15 \mathrm{~mm}$ when a mature sample was not available) were collected from the wood collections of Tervuren (Tw; 67 species), Naturalis Biodiversity Center (Lw, WAGw, Uw; 75 species), and Thünen Institute (RBHw; 112 species). In total, 93 original wood anatomical descriptions are provided in this study, and added to existing, unpublished descriptions by H. Gottwald ( 72 species; summary available in Gottwald 1984), F. Lens ( 25 species; Lens 2005), S. Pronk (29 species; Pronk 2008), and A. Pletsers (28 species; Pletsers 2006). In addition, we collected seven extra Malagasy species from the Thünen Institute (Hamburg, Germany) which had already been described in (Ravaomanalina et al. 2017). To increase consistency across wood anatomical descriptions from different persons, we have done extra observations to standardize features that were measured differently (e.g., Gottwald measured vertical intervessel pit diameter instead of horizontal diameter as recommended by IAWA Committee (1989)), and to complement features that were not measured (e,g., extra maceration slides needed to measure vessel element and fibre length for several species).

\section{Wood slides preparation and light microscopy}

Wood samples of approximately $1 \mathrm{~cm}^{3}$ were put in water at $70-80^{\circ} \mathrm{C}$ for one day. Transverse, tangential, and radial sections of about $21-25 \mu \mathrm{m}$ in thickness were cut using a sledge microtome (Reichert, Vienna, Austria). After sectioning, the wood sections were pressed between two glass microscope slides and placed in warm water overnight. After bleaching with sodium hypochlorite $1-3 \%$ for 1 minute (three minutes for black sections) and rinsing with distilled water, the sections were briefly stained with a 1:2 mixture of safranin ( $0.5 \%$ in $50 \%$ ethanol) and alcian blue ( $1 \%$ in water) for 15 seconds (only $3-5$ seconds for black sections); after staining, the sections were dehydrated in an ethanol series $(5 \circ \%, 70 \%$, 96\%), treated with Histoclear clearing agent (AURION Immuno Gold Reagents and Accessories, Wageningen, The Netherlands) and mounted in Euparal (Carl Roth, Waldeck, Germany). The slides were then stored in an oven at $50^{\circ} \mathrm{C}$ for a minimum of 6 weeks with weights on top of the slides. Maceration slides were prepared according to (Franklin 1945). The wood sections were examined with a Leica DM25oo light microscope with objective lenses in the range of $5^{-40 \times(N A ~ 0.12-0.75) ~ a n d ~ p h o t o g r a p h e d ~ w i t h ~ a ~ L e i c a ~ D F C-425 C ~}$ 
digital camera (Leica Microscopes, Wetzlar, Germany). The wood anatomical terminology follows the 'IAWA list of microscopic features for hardwood identification' (IAWA Committee 1989).

\section{Scanning electron microscopy}

A total of 17 Diospyros species (D. caribaea, D. cinnabarina, D. cooperii, D. dictyoneura, D. heterotricha, D. heudelotii, D. lolin, D. longistyla, D. maingayi, D. malabarica, D. mannii, D. montana, D. piscatoria, D. pseudoxylopia, D. texana, D. vignei, and D. virginiana), one Royena (R. lucida) and one Lissocarpa species (L. guianensis) were selected for SEM observations. The selection was based on the presence of characters for which high magnification illustrations (such as crystals, pits, or vessel wall sculpturing) were desired. For each of the ten species, $1 \mathrm{~cm}^{3}$ per wood sample was boiled for one day at 90 degrees. With a razor blade, the boiled wood sample was split in a tangential and radial plane, resulting in two orientations of one sample. The wood surfaces were submerged in $4 \%$ sodium hypochlorite for one hour. Next, the surfaces were rinsed three times with distilled water and subsequently dehydrated in $50 \%, 70 \%$, and $95 \%$ alcohol for 10 minutes each. The samples were then air-dried, mounted on a stub, coated with platinum-palladium in a Quorum Q150TS sputter coater (Quorum Technologies, Laughton, UK), and observed with a Jeol JSM-76ooF field emission scanning electron microscope (JEOL, Tokyo, Japan) at a voltage of $5 \mathrm{kV}$.

\section{Phylogenetic reconstruction}

Phylogenetic reconstruction of Ebenaceae was mostly based on the aligned matrix from Duangjai et al. (2009) based on four chloroplast markers: atpB, rbcL, trnK-matK, and trnS$G$; DNA sequences from 16 species were added based on a more recent study (Linan et al. 2019). Only species for which wood anatomical descriptions could be generated were included (88 species, including 81 Diospyros species). Nucleotide substitution models were tested using the Akaike Information Criterion (AIC) in jModeltest v.2.1.10 for each gene region individually (Darriba et al. 2012) (see Table A2 in the Appendix). Bayesian phylogenetic reconstruction was carried out using BEAST v.2.6.1 (Bouckaert et al. 2014). Each of the four gene regions was given its own partition and analysed under the log-relaxed lognormal molecular clock and Yule speciation process with the preferred substitution model as determined by jModeltest. We used the (Linan et al. 2019) protocol for setting the ingroup time calibration priors (see Tables $\mathrm{A}_{3}$ and $\mathrm{A}_{4}$ in the Appendix). Two independent Markov chain Monte Carlo (MCMC) runs were simulated. Each run had a 50 -million chain length. By sampling every 1000 generations, 50 ooo trees were produced for each run. LogCombiner v.2.6.1 and TreeAnnotator v.2.6 were used, respectively, to combine the resulting trees and build a maximum clade credibility (MCC) tree (burn-in $=20 \%$ ). Convergence of all runs separately and the combined runs was evaluated with Tracer v.1.7.1 (Rambaut et al. 2014). 


\section{Ancestral state reconstruction}

We assessed the ancestral state reconstructions with three main approaches: stochastic character mapping (SCM), Maximum Likelihood (ML), and Reversible-Jump Markov chain Monte Carlo (RJ-MCMC). For the ML approach, we used the ACE function implemented in the R-package 'phytools' with three models: all rates different (ARD), equal rates (ER), and symmetrical (SYM) models relying on a re-rooting method (Yang et al. 1995). The best-fitting model was selected based on likelihood ratio tests. For the SCM, we performed 1000 simulations ( $\mathrm{nsim}=1000$ ) on the MCC tree. Results of the proportion of time spent in each state and transitions were summarised with the functions 'make.simmap' and 'describe.simmap' from the 'phytools' package. We performed these analyses following previously published scripts (Bogarín et al. 2019). RJ-MCMC analyses were executed in the program BayesTraits V3.0.2 by selecting the Multistate and MCMC options under the following conditions: $5^{\circ}$ million iterations, sample period of 1000, with the first 10 million iterations discarded as the burn-in, using the AddNode option to reconstruct ancestral states, stepping-stone simulation with 100 steps, sampling 10 ooo states from each step and the revjump option with an exponential prior with a mean of 10 (Meade \& Pagel 2016).

\section{RESULTS}

\section{Wood anatomical descriptions (Figs. 1-3)}

An overview of the most important wood anatomical features is provided in Table A1 in the Appendix. A summary description for Diospyros (based on 246 species including the Malagasy species) studied is given below.

Growth rings generally indistinct or absent (Fig. 1), but distinctly marked by relatively thick-walled latewood fibres in Diospyros acuminata, D. andamanica, D. anisandra, D. apiculata, D. areolata, D. argentea, D. bipindensis, D. bourdilloni, D. brandisiana, D. bullata, D. bussei, D. canaliculata, D. chevalieri, D. christophersenii, D. clusiifolia, D. confertiflora, D. conocarpa, D. conzattii, D. crassiflora, D. dasyphylla, D. dendo, D. dichrophylla, D. dictyonema, D. ebenifera, D. euphlebia, D. fasciculosa, D. frutescens, D. glandulosa, D. grex, D. guatterioides, D. hallierii, D. heterotricha, D. hillebrandii, D. inconstans, D. insularis, D. juruensis, D. kaki, D. lasiocalyx, D. lissocarpoides, D. longibracteata, D. lotus, D. macrophylla, D. maingayi, D. managabensis, D. martini, D. matheriana, D. morrisiana, D. mweroensis, D. natalensis, D. nicaraguensis, D. pallens, D. palmeri, D. philippinensis, D. pyrrhocarpa, D. quaesita, D. samoensis, D. sandwicensis, D. saxosa, D. sericea, D. squamosa, D. squarrosa, D. tenuiflora, $D$. tetrasperma, D. texana, D. toposia, D. toxicaria, D. venosa, D. verrucosa, D. virginiana (Fig. 1A), $D$. viridicans and $D$. vitiensis. Wood almost always diffuse-porous, semi-ring-porous in $D$. virginiana (Fig. 1A) and variably diffuse to weakly semi- ring- porous in some samples of D. kaki and $D$. lotus. Tangential diameter of vessels $(10)-50-115^{-}(260) \mu \mathrm{m}$, vessel elements (8o)-29o-635-(1300) $\mu \mathrm{m}$ long. Vessels (1)-15-30-(26o) $/ \mathrm{mm}^{2}$, usually solitary and in radial multiples of 2-5-(10) (Fig. 1A-C), sometimes also clusters up to 13 vessels (Fig. $1 \mathrm{D})$, predominantly solitary vessels in $D$. argentea, D. barteri, $D$. conocarpa, D. conzattii, D. cooperii, $D$. ebenum (Fig. 1E), D. ferruginescens, D. fragrans, D. grisebachii, D. Lolin, D. managabensis, D. philippinensis, D. pilosanthera, D. puncticulosa, D. squamosa and D. tenuiflora. Vessel outline circular. Vessel perforation plates always simple (Fig. 2A). Intervessel pits predominantly 

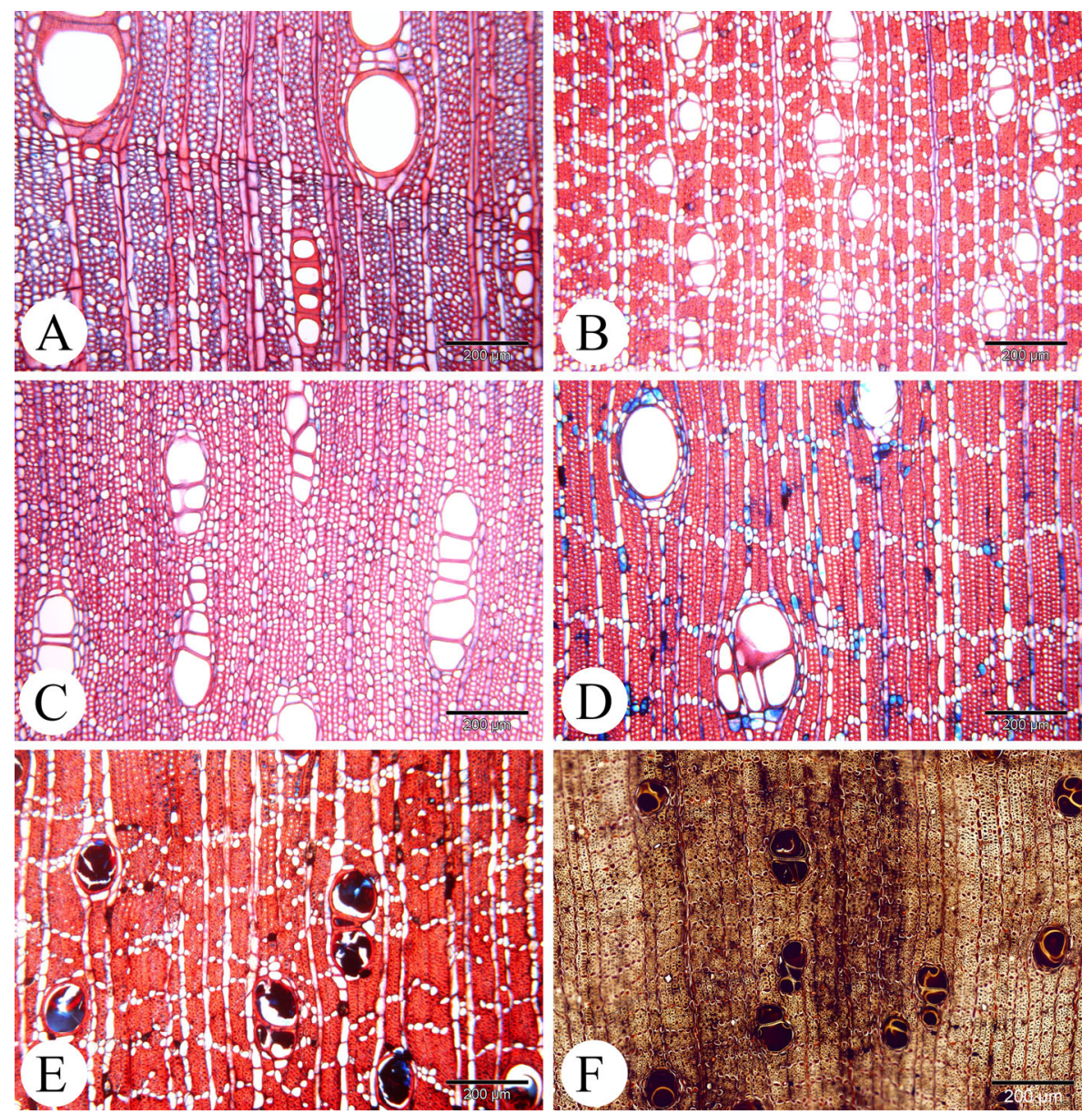

Figure 1. Microscopic images of Diospyros wood sectioned in a transverse orientation. (A) Diospyros virginiana, semi ring-porous, vessels solitary or in short radial multiples, scanty to vasicentric paratracheal parenchyma (B) Diospyros ferrea, vessels solitary or in short radial multiples, banded apotracheal parenchyma, scanty to vasicentric paratracheal parenchyma. (C) Diospyros heterotricha, vessels mainly in radial multiples, axial parenchyma diffuse-in-aggregates with slight tendency to form short interrupted bands. (D) Diospyros malabarica, vessels solitary or in clusters, banded apotracheal, and scanty to vasicentric paratracheal parenchyma. (E) Diospyros ebenum, black heartwood, unstained, vessels solitary or in short radial multiples, thick-walled fibres. (F) Diospyros perrieri, black heartwood, vessels solitary or in short radial multiples, banded axial parenchyma, thick-walled fibres.

alternate (Fig. 2B) or alternate to opposite, intervessel pits (3)-4-6-(10) $\mu \mathrm{m}$ in horizontal diameter. Vessel-ray pits predominantly alternate or alternate to opposite, distinctly bordered, pits (3)-4-6-(10) $\mu \mathrm{m}$ in horizontal diameter, often unilaterally compound. Helical thickenings absent. Tracheids absent. Fibres non-septate, mostly with simple to minutely 

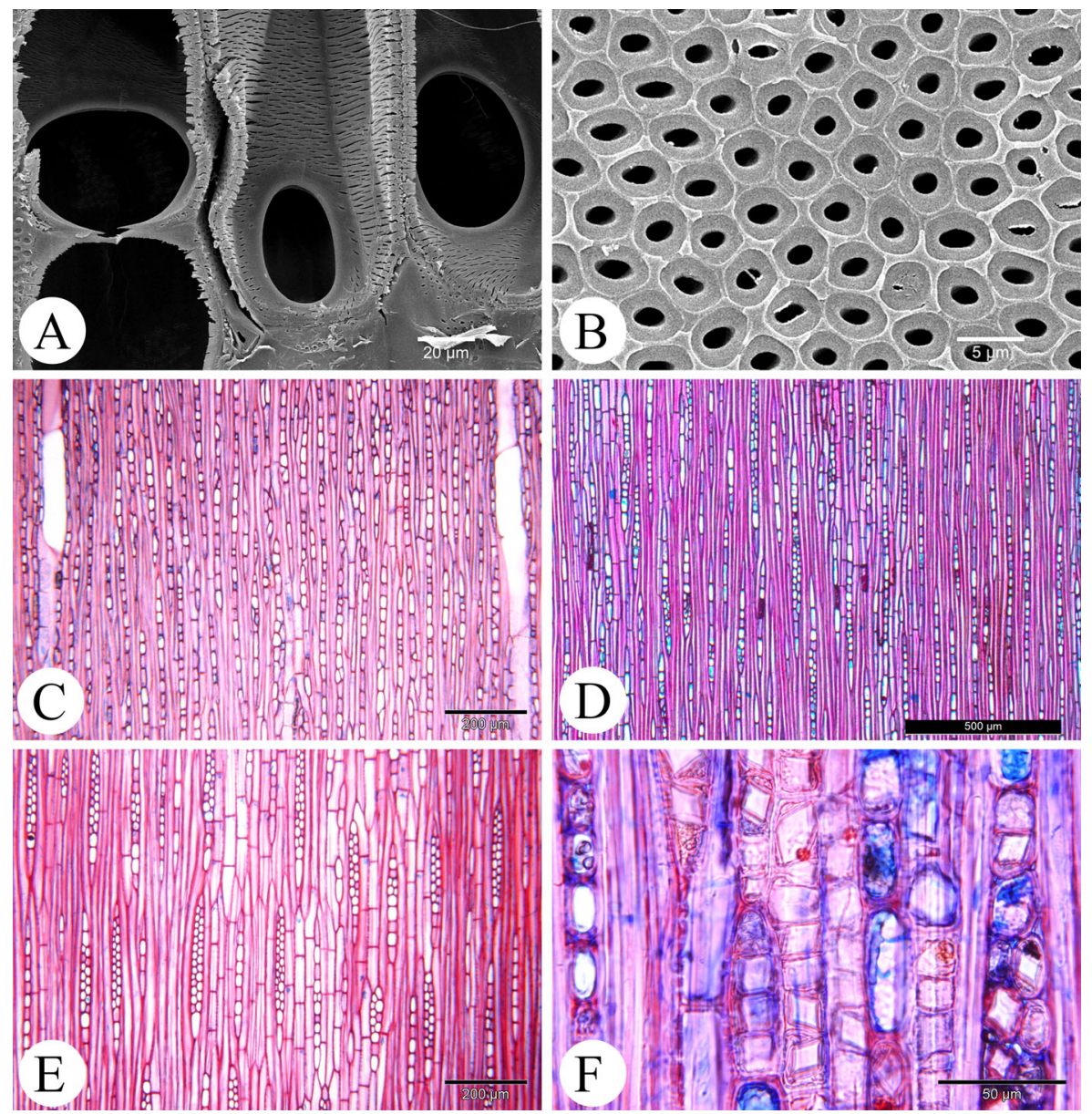

Figure 2. Illustrations of longitudinal SEM surfaces (A, B) and tangential light microscope (LM) sections (C-F) of Diospyros wood. (A) Diospyros heterotricha, radial section, simple vessel perforations. (B) Diospyros caribaea, tangential section, alternate intervessel pits. (C) Diospyros heterotricha, tangential section, rays predominantly uniseriate. (D) Diospyros lanceifolia, tangential section, uniseriate and multiseriate. (E) Diospyros morissiana, tangential section, storied structures. (F) Diospyros natalensis, tangential section, prismatic crystals in chambered axial parenchyma, and ray cells.

bordered pits concentrated in radial walls, or sometimes with distinctly bordered pits concentrated in tangential and radial walls. Fibres (390)-770-1340-(2550) $\mu \mathrm{m}$ long and usually thin-to-thick walled (Fig. $1 \mathrm{D}$ ), but very thick-walled in D. amazonica, D. analamerensis, $D$. borneensis, D. brandisiana, D. bullata, D. celebica, D. cinnabarina, D. conocarpa, D. crassinervis, D. cupulifera, D. dichroa, D. discolor, D. ebenum (Fig. $1 \mathrm{E}$ ), D. ferrea (Fig. 1B), D. fragrans, D. gabunensis, D. haplostylis, D. humbertiana, D. impressinervis, D. iturensis, D. kamerunensis, D. korthalsiana, D. kurzii, D. lanceolata, D. lokohensis, D. longistyla, D. martini, D. mellinoni, 


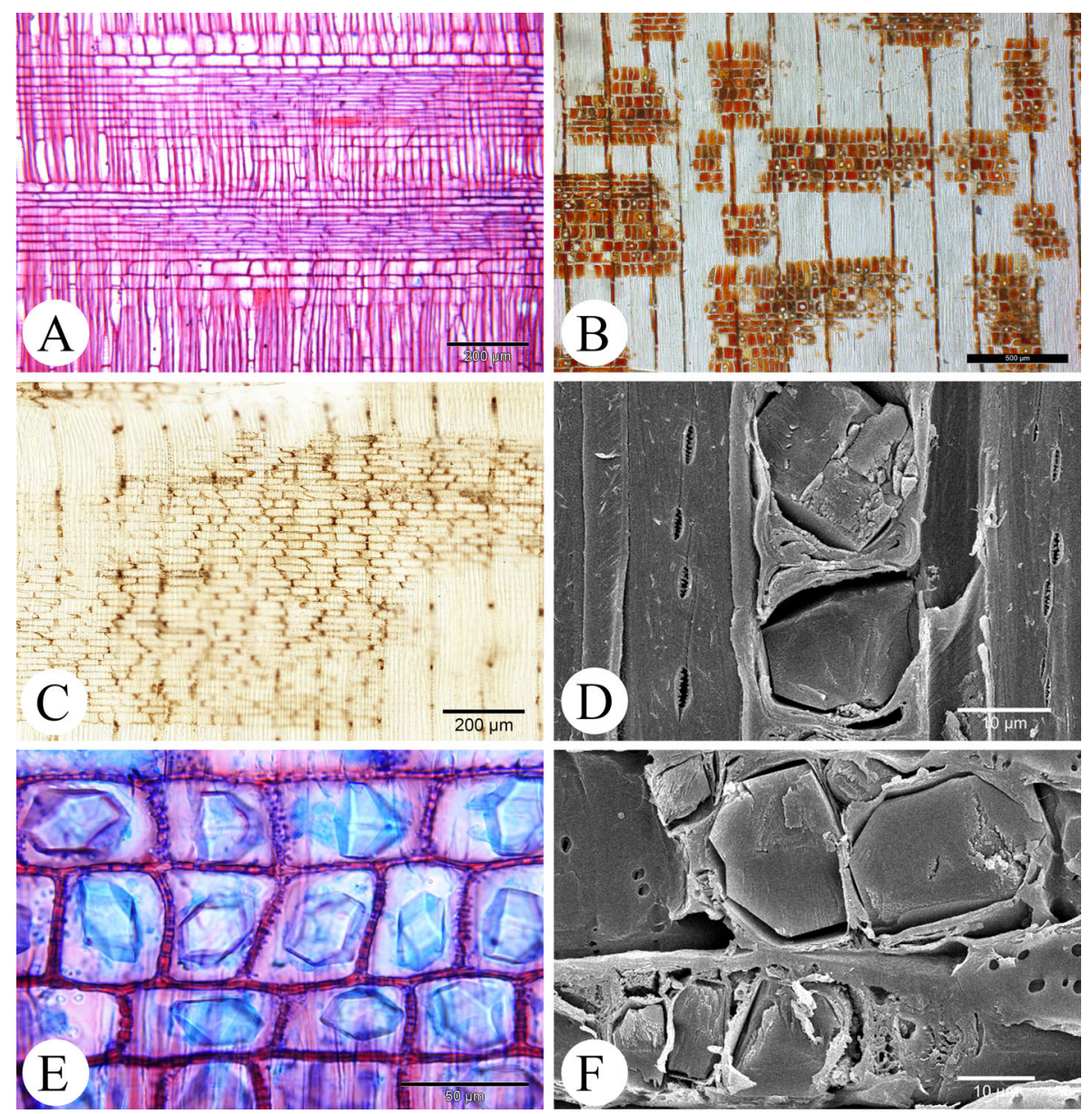

Figure 3. Illustrations of longitudinal sections (LM) and surfaces (SEM). (A) Diospyros morissiana, radial section, heterocellular rays. (B) Diospyros oblonga, radial section, unstained, heterocellular rays. (C) Diospyros maingayi, radial section, unstained, homocellular rays. (D) Diospyros cooperi, tangential section, prismatic crystals in chambered axial parenchyma cells. (E) Diospyros mespiliformis, radial section, prismatic crystals in rays. (F) Diospyros caribaea, radial section, prismatic crystals in rays.

D. mespiliformis, D. mindanaensis, D. mollis, D. montana, D. myriophylla, D. natalensis, D. nidiformis, D. nitida, D. occlusa, D. olacinoides, D. perfida, D. perrieri (Fig. IF), D. pervilleana, D. philippinensis, D. pilosanthera, D. platycalyx, D. poncei, D. pseudoxylopia, D. ridleyi, D. rostrata, D. sandwicensis, D. sogeriensis, D. soubreana, D. spinescens, D. squarrosa, D. subrhomboidea, D. tetrandra, D. tsaratananensis, D. velutipes, D. vescoi and D. vignei and thin-walled in D. artanthifolia, D. buxifolia, D. coriacea, D. curraniopsis, D. dasyphylla, D. dictyonema, $D$. hallierii, D. heterotricha (Fig. 1 C), D. kirkii, D. lanceifolia, D. lotus, D. malam, D. minahasae, D. morrisiana and $D$. texana. Apotracheal axial parenchyma mostly in narrow bands (usually 
continuous (reticulate) or sometimes interrupted) of 1-2-(3) cells wide (Fig. 1B, D-F), sometimes diffuse-in-aggregates (Fig. 1A, C), paratracheal parenchyma always as a combination of scanty or scanty to vasicentric axial parenchyma (Fig. 1A-D), strands of (2)-3-6-(12) cells. Uniseriate rays always present and often more frequent than multiseriate rays (Fig. $2 \mathrm{C}$ ), (50)-190-715-(1620) $\mu \mathrm{m}$ high, consisting of procumbent or upright cells (Fig. 3A), (1)-9-14(35) rays $/ \mathrm{mm}$. Multiseriate rays 2-(3)-seriate (Fig. $2 \mathrm{D}-\mathrm{F}$ ), (80)-250-80o-(2300) $\mu \mathrm{m}$ high, consisting of mainly procumbent (sometimes square) body cells, and 1-4 marginal rows of upright (sometimes square) cells (Fig. 3A, B), (1)-3-6-(13) rays/mm. Homocellular rays with nearly all ray cells procumbent in $D$. andamanica, D. bejaudii, $D$. dichroa, D. discolor, D. ebenaster, D. euphlebia, D. grex, D. hallierii, D. hebecarpa, D. lolin, D. longibracteata, D. maingayi, D. manausensis, D. mannii, D. mollis, D. monbuttensis, D. morrisiana, D. olacinoides, D. pervilleana, D. pilosanthera, D. poncei, D. pseudoxylopia, D. ridleyi, D. sogeriensis, D. soubreana, $D$. subrhomboidea, $D$. tenuiflora, $D$. trichophylla, $D$. variegata and $D$. walkeri. Sheath cells absent. Prismatic crystals common in either (mostly chambered) axial parenchyma cells (Fig. ${ }_{2} \mathrm{~F}$ ) or (mostly non-chambered) ray cells (Fig. ${ }_{3} \mathrm{E}$ ). No mineral inclusions observed in $D$. bejaudii, D. bullata, D. evena, D. ferruginescens, $D$. foxworthyi, D. guianensis, D. heterotricha, $D$. hirsuta, D. lasiocalyx, D. longistyla, D. macrophylla, D. muricata, D. nilagirica, D. pentamera, D. pseudoxylopia, D. rufa, D. toposia, and D. tristis. Storied structures (vessel elements, fibres, axial parenchyma, and rays) presents only in D. glandulosa, D. kaki, D. lotus, D. morissiana (Fig. 2E), and D. virginiana.

The following wood description is based on the 29 Malagasy Diospyros species observed: Growth rings typically indistinct or absent, but distinct and marked by relatively thickwalled latewood fibres in D. managabensis, D. squamosa, D. squarrosa, and D. toxicaria. Wood diffuse-porous. Tangential diameter of vessels (10)-30-70-(120) $\mu \mathrm{m}$, vessel elements (150)-250-530-(1000) $\mu \mathrm{m}$ long. Vessels $(2)-5 \mathrm{o}-8 \mathrm{o}-(260) / \mathrm{mm}^{2}$, usually solitary and in radial multiples of $2-8-(10)$. Vessel outline circular. Vessel perforation plates always simple. Intervessel pits alternate to opposite and between $3^{-7} \mu \mathrm{m}$ horizontal diameter; vessel ray pits mostly alternate to opposite and $3-7 \mu \mathrm{m}$ in horizontal diameter. Fibre pits simple to minutely bordered in radial walls, fibres usually very thick-walled, but thin to thick-walled in D. aculeata, D. calophylla, D. conifera, D. fuscovelutina, D. leucocalyx, D. managabensis, $D$. megaphylla, D. namoroensis, $D$. scalerophylla, D. squamosa, D. toxicaria, and D. tropophylla, between (400)-750-126o-(1700) $\mu \mathrm{m}$ long. Apotracheal parenchyma mostly banded in the shape of short interrupted bands or continuous bands (reticulate) with strands of 2-5(8) cells, paratracheal parenchyma scanty or scanty to vasicentric. Rays mostly uni- and multiseriate but exclusively uniseriate in D. analamerensis, D. calophylla, D. olacinoides, $D$. perrieri, D. conifera, D. velutipes, D. leucocalyx, D. pervilleana, D. managabensis, D. haplostylis, D. namoroensis, D. squamosa, D. lokohensis and D. tropophylla, with uniseriate ray height from (75)-18o-65o-(160o) $\mu \mathrm{m}$, number of rays per mm a (3)-11-16-(35), multiseriate

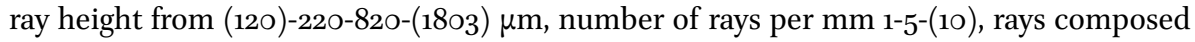
of mostly procumbent/(square) body ray cells with 1-4 upright marginal ray cells. Prismatic crystals in chambered axial parenchyma cells (exclusively in non-chambered cells of Diospyros squamosa), together with few crystals in non-chambered ray cells. Storied structures absent. 
For wood descriptions and anatomical illustrations of the other genera (Euclea, Lissocarpa, and Royena), see see Table A1 in the Appendix.

\section{Ancestral state reconstruction}

Based on the variation of wood characters throughout the genus, eight potential phylogenetically informative characters were selected for ancestral state reconstruction analysis of which four are visualised (Fig. 4): apotracheal parenchyma distribution (banded,
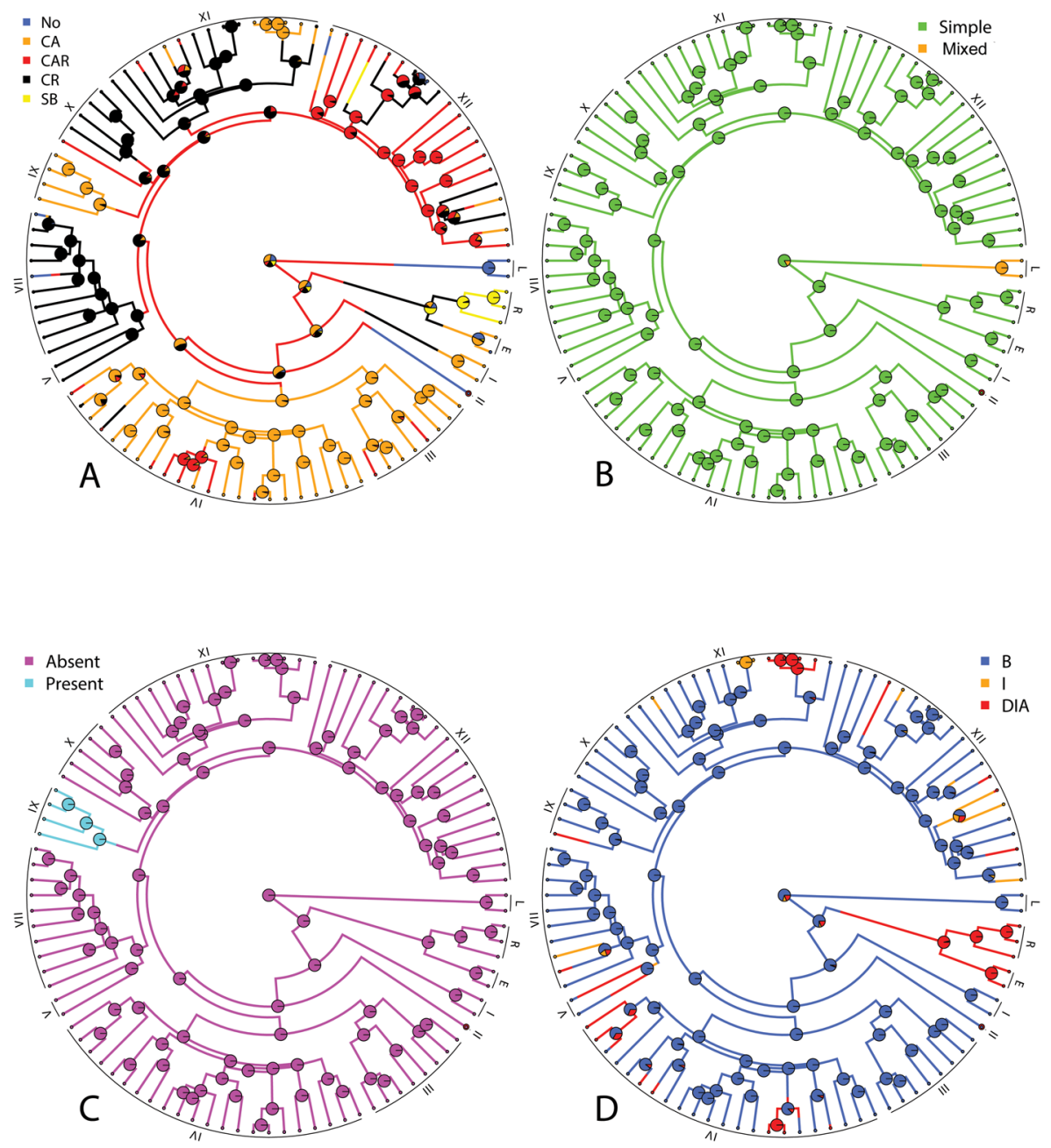

Figure 4. Ancestral state reconstructions of selected wood anatomical characters from stochastic character mapping analyses. (A) Location of mineral inclusions (No: no mineral inclusions observed, CA: crystals in axial parenchyma cells, CAR: crystals in either axial parenchyma and ray cells, CR: crystals in rays, SB: silica bodies present). (B) Vessel perforation plates. (C) Storied structures. (D) Apotracheal parenchyma distribution (B: banded, IB: interrupted bands, DIA: diffuse-in-aggregates). 
interrupted bands, diffuse-in-aggregates), mineral inclusions (prismatic crystals in axial parenchyma, prismatic crystals in rays, prismatic crystals in either axial parenchyma and rays, silica bodies in rays, no mineral inclusions), storied structure (absent, present) and vessel perforation plates (exclusively simple, mixed simple and scalariform). For the other traits including ray width (predominantly uniseriate, uniseriate, and multiseriate), vessel grouping (predominantly solitary, predominantly in radial multiples, solitary and in radial multiple), paratracheal parenchyma (scanty, scanty to vasicentric and vasicentric), uniseriate ray height (short, medium and long), see Table A2 in the Appendix. The ancestral trait reconstruction for the three remaining characters are: uniseriate ray height (short $<400$ $\mu \mathrm{m}$, medium $400-700 \mu \mathrm{m}$ and long $>700 \mu \mathrm{m}$ ), multiseriate ray height (short, medium, long), and paratracheal parenchyma (scanty, scanty to vasicentric, vasicentric). The loglikelihood test shows that the ER model fits much better than ARD and slightly better than SYM (see Table $A_{5}$ in the Appendix). The ACE and SIMMAP yielded identical scaled likelihoods at the root state. The RJ-MCMC revealed different results for vessel perforation plates with ambiguous estimations for the characters of uniseriate and multiseriate ray height, mineral inclusion, and vessel grouping. ACE and SIMMAP suggest the following features based on their marginal probability for the family root state: apotracheal parenchyma with regular narrow bands along with scanty paratracheal parenchyma, crystals in either rays or axial parenchyma, non-storied short rays, vessels with exclusively simple perforation plates solitary to radial multiples grouping (RJ-MCMC analysis suggests simple and scalariform vessel perforation plates). None of the methods estimates any clear root state for ray width.

\section{DISCUSSION}

This study presents the most extensive wood anatomical survey of the ebony wood genus Diospyros to date. It includes descriptions of 246 species (representing novel descriptions of 93 species, and revised descriptions of 153 species from previous unpublished studies) that cover all geographic ranges and all of the major subclades of Diospyros (see Fig. A3 in the Appendix).

\section{Diversity and evolutionary patterns in the wood anatomy of Ebenaceae and related families}

The descriptions of our extended ebony wood dataset are largely in agreement with the earlier wood anatomical studies (Gottwald 1984; Lens 2005; Morton 1994; Richter 2000). Diospyros is characterized by simple-perforated vessels often arranged in radial multiples in combination with solitary vessels, vessels mainly with alternate intervessel pits, fibres non-septate with mostly simple to minutely bordered pits, axial parenchyma mainly apotracheal and often distributed in interrupted or complete bands of one cell wide, uniseriate rays often co-occurring with narrow and short multiseriate rays, and prismatic crystals present either in chambered axial parenchyma or non-chambered ray cells. Euclea cannot be separated from Diospyros based on the wood anatomical structure. The South African genus Royena, however, can easily be distinguished from Diospyros (and the other Ebenaceae genera) based on the presence of silica bodies in the rays. (Morton 1994) also 
observed silica in three species of the genus Diospyros (D. acuminata, D. montana, and D. sylvatica), but our observations combined with those of Gottwald did not confirm this. In one species, Royena lycioides, a couple of prismatic crystals in rays were observed next to the abundant silica bodies. Finally, the combination of unique wood anatomical characters in the South American Lissocarpa, such as the sporadic occurrence of scalariform perforations with many bars (up to 30 ), the relatively long vessel elements and fibres (ca. 1000 and $2000 \mu \mathrm{m}$, respectively), long multiseriate rays (1000-1500 $\mu \mathrm{m}$ ), and the lack of mineral inclusions, corroborate the isolated position of this genus as sister to all the other Ebenaceae (see Appendix). Especially the presence of scalariform perforations is interesting and provides extra support for the many independent transitions from scalariform to simple-plated clades across the asterids clade (Lens et al. 2016).

The Ebenaceae family belongs to the order of the Ericales, with the extended Primulaceae and Sapotaceae as sister groups (Larson et al. 2020; Rose et al. 2018). From a wood anatomical point of view, the Ebenaceae are most similar to Sapotaceae due to the shared occurrence of banded axial parenchyma (also present in Lecythidaceae), short multiseriate rays (less than $1 \mathrm{~mm}$; also in Styracaceae and sometimes in Lecythidaceae), the presence of storied structure in at least one genus (also in Primulaceae), and crystals in chambered axial parenchyma cells (also in Lecythidaceae and Styracaceae) (Dickison \& Phend 1985; Lens et al. 2005, 2007). On the other hand, Ebenaceae wood can be easily distinguished from Sapotaceae by the presence of distinctly bordered vessel-ray pits (versus two distinct types of vessel-ray pitting in Sapotaceae), absence of crystal sand (versus presence in Sapotaceae), and the dominance of uniseriate rays (versus uniseriate rays scarce in Sapotaceae) (Lens 2005).

Although the sampling for ancestral state reconstruction was reduced to 88 Ebenaceae species to match the species overlap between our wood anatomical database and the available molecular phylogenies, we could find a number of wood anatomical traits that seem to have high phylogenetic signal across Ebenaceae as well as within Diospyros. The presence of silica bodies only occurs in Royena (Fig. 4A) and the mixed presence of scalariform and simple perforation plates defines the genus Lissocarpa (Fig. $4 \mathrm{~B}$ ). This unique occurrence of mixed perforation plates in the genus that is sister to all other Ebenaceae is interesting from an evolutionary point of view: it is consistent with the Baileyan trends corresponding to evolutionary transitions from scalariform to simple perforation plates that have evolved in a dozen of early diverging lineages throughout the asterids, probably triggered by peak conductive rates (Lens et al. 2016). Consequently, it is likely that the ancestor of Ebenaceae had a proportion of scalariform perforations as well, which was reconstructed with RJ-MCMC but not with the other methods (Fig. $4 \mathrm{~B}$ ).

With respect to presence and location of prismatic crystals, some interesting evolutionary and biogeographic patterns can be retrieved: absence of crystals may be ancestral within the family (Fig. 4A), and crystals could have been lost in 18 Diospyros species (D. bejaudii, D. bullata, D. evena, D. ferruginescens, D. foxworthyi, D. guianensis, D. heterotricha, $D$. hirsuta, D. lasiocalyx, D. longistyla, D. macrophylla, D. muricata, D. nilagirica, D. pentamera, D. pseudoxylopia, D. rufa, D. toposia, and D. tristis). Interestingly, crystals seem to have developed first in axial parenchyma and are mostly confined to species native to 
Africa, including all the species observed from Madagascar, while crystal occurrence in rays evolved later in species that are mainly distributed in Asia. In addition to this biogeographic pattern, the position of crystals in axial parenchyma or rays can be used as a synapomorphy to define subclades IV, VII, and XII. Another character with clear phylogenetic signal is the presence of storied structure (Fig. $4 \mathrm{C}$ ). There are only four species that are characterized by storied structure: D. glandulosa, D. kaki, D. lotus, and D. virginiana. These species all belong to Diospyros clade IX and also show a tendency to form vasicentric parenchyma (the latter is also present in a number of species outside clade IX, see Fig. A2C in the Appendix). Diospyros japonica is also part of Diospyros clade IX following Duangjai et al. 2009 (included as D. glaucifolia) and has storied structures as well (InsideWood, 2004-onwards; Wheeler 2011). The presence of storied structures in D. crassiflora and $D$. ehretioides by Lens (2005) could not be supported in this study based on multiple samples of both species.

Then there are a number of features in Ebenaceae with weaker phylogenetic signals, such as uniseriate and multiseriate ray height. Multiseriate rays are often longer (on average $700 \mu \mathrm{m}$ or more) in the early-diverging Ebenaceae lineages (Lissocarpa, Euclea, Royena, although there is some variation), pointing to an evolutionary shortening of rays when moving up from the basal lineages to the tips of the phylogeny. For apotracheal parenchyma distribution (Fig. $4 \mathrm{D}$ ), the banded pattern is characteristic of most clades with multiple transitions towards interrupted bands or diffuse-in-aggregates (e.g. Royena and Euclea). For vessel grouping (Fig. $4 \mathrm{E}$ ), the main type is solitary mixed with radial vessel multiples, with multiple transitions towards mainly radial multiples (e.g. Royena) or mainly solitary vessels.

\section{Bottlenecks in wood identification of CITES protected ebony from Madagascar}

Based on our current sampling, we are unable to distinguish Malagasy from nonMalagasy wood samples based on microscopic anatomy, which has also been reported in the database CITESwoodID (Richter et al. 2014). This problem is mainly related to the wood anatomical resemblance across Diospyros species, the occurrence of Malagasy species in multiple clades (see Fig. A2 in the Appendix), and further hampered by the "chaotic" taxonomy situation resulting in overlapping species descriptions, many undescribed species, and poor sampling of Diospyros (29 out of 246 Diospyros species in our study). This is in line with other wood anatomical studies that have repeatedly demonstrated that species identification based on wood anatomy is often not possible, especially when trying to identify close relatives belonging to the same genus (Gasson 2011; Koch et al. 2011). However, wood anatomy can give us some arguments to confirm that an unknown ebony wood sample is not derived from Madagascar, for instance by the presence of crystals predominantly in rays and presence of storied structure. To improve species identification of ebony woods, we are currently applying a complementary chemical profiling technique based on DART TOFMS. This chemical profiling method uses species-specific wood chemical composition in order to identify species (Cody et al. 2005) and has been successfully applied to several tree genera, such as Aquilaria (Lancaster \& Espinoza 2012; Espinoza et al. 
2014), Dalbergia (Lancaster \& Espinoza 2012; Espinoza et al. 2014), and Quercus (Cody et al. 2012).

To conclude, this study presents wood anatomical observations in a phylogenetic framework based on the world's largest reference collection of ebony woods to date. Within the Ebenaceae family, Lissocarpa and Royena can be easily distinguished from the other Ebenaceae genera by the presence of mixed simple and scalariform vessel perforation plates and the occurrence of silica bodies, respectively. Also, the clade of Diospyros species producing edible fruits (clade IX) is strongly supported by storied structures. Likewise, the position of prismatic crystals characterises several molecular-based clades and relates to general biogeographical patterns, but other characters such as axial parenchyma distribution, number of cells per axial parenchyma strand, ray width and height, and ray composition, are highly homoplasious. At this point, we are not able to distinguish CITES protected Malagasy species from the rest based on microscopic wood anatomy, but a better sampling from Malagasy woods and integration of wood anatomy with complementary datasets based on chemical profiling will hopefully generate an improved identification tool for ebony woods in the future.

\section{ACKNOWLEDGEMENTS}

The first authors contributed equally to this work. This paper is dedicated to Helmut Gottwald (Thünen Institute, Hamburg, Germany), who devoted much of his scientific career to the wood anatomy of ebony wood. We thank Sander Pronk and Annelies Pletsers for sharing their unpublished wood anatomical descriptions, Bertie-Joan van Heuven and Rob Langelaan for their support with laboratory work, Mary Rosabelle Samuel, Ovidiu Paun, and Sutee Duangjai for sharing alignments, and Diego Bogarín, Roderick Bouman, and Rutger A. Vos for their help with phylogenetic and ancestral trait reconstruction analyses. This study was supported by Plant.ID Innovative Training Networks, which has received funding from the European Union's Horizon 2020 research and innovation programme under Marie Skłodowska-Curie grant agreement No 765000 .

\section{REFERENCES}

Belemtougri RG, Constantin B, Cognard C, Raymond G, Sawadogo L. 20o6. Effects of two medicinal plants Psidium guajava L. (Myrtaceae) and Diospyros mespiliformis L. (Ebenaceae) leaf extracts on rat skeletal muscle cells in primary culture. J. Zhejiang Univ. Sci. B 7: 56-63. DOI: 10.1631/jzus. 2006.Boo56.

Bogarín D, Pérez-Escobar OA, Karremans AP, Fernández M, Kruizinga J, Pupulin F, et al. 2019. Phylogenetic comparative methods improve the selection of characters for generic delimitations in a hyperdiverse Neotropical orchid clades. Sci. Rep. 9: 15098. DOI: 10.1038/s41598-o19-5136o-o.

Bouckaert R, Heled J, Kühnert D, Vaughan T, Wu C-H, Xie D, et al. 2014. BEAST 2: a software platform for Bayesian evolutionary analysis. PLoS Comput. Biol. 10: e1003537. DOI: 10.1371/journal.pcbi. 1003537 .

Brown HP, Panshin AJ. 1940. Commercial timbers of the United States: their structure, identification, properties, and uses. McGraw-Hill, New York, NY.

Cody RB, Dane AJ, Dawson-Andoh B, Adedipe EO, Nkansah K. 2012. Rapid classification of White Oak (Quercus alba) and Northern Red Oak (Quercus rubra) by using pyrolysis direct analysis in realtime (DARTTM) and time-of-flight mass spectrometry. J. Anal. Appl. Pyrolysis 95: 134-137. DOI: 10.1016/j.jaap.2012.01.018. 
Cody RB, Laramée JA, Durst HD. 2005. Versatile new ion source for the analysis of materials in open air under ambient conditions. Anal. Chem. 77: 2297-2302. DOI: 10.1021/aco50162j.

Darriba D, Taboada GL, Doallo R, Posada D. 2012. jModelTest 2: more models, new heuristics, and parallel computing. Nat. Methods 9: 772. DOI: 10.1038/nmeth.2109.

Détienne P, Jacquet P. 1983. Atlas d'identification des bois de l'Amazonie et des régions voisines. Centre Technique Forestier Tropical, Nogent s/Marne. 640 pp.

Dickison WC, Phend KD. 1985. Wood anatomy of the Styracaceae: evolutionary and ecological considerations. IAWA J. 6: 3-22. DOI: 10.1163/22941932-90ooogo3.

Dormontt EE, Boner M, Braun B, Breulmann G, Degen B, Espinoza E, et al. 2015. Forensic timber identification: it's time to integrate disciplines to combat illegal logging. Biol. Conserv. 191: 79o-798. DOI: 10.1016/j.biocon.2015.06.o38.

Duangjai S, Samuel R, Munzinger J, Forest F, Wallnöfer B, Barfuss MHJ, et al. 20og. A multi-locus plastid phylogenetic analysis of the pantropical genus Diospyros (Ebenaceae), with an emphasis on the radiation and biogeographic origins of the New Caledonian endemic species. Mol. Phylogenet. Evol. 52: 6o2-620. DOI: 10.1016/j.ympev.2009.04.021.

Espinoza EO, Lancaster CA, Kreitals NM, Hata M, Cody RB, Blanchette RA. 2014. Distinguishing wild from cultivated agarwood (Aquilaria spp.) using direct analysis in real-time and time-of-flight mass spectrometry. Rapid Commun. Mass Spectrom. 28: 281-289. DOI: 10.1002/rcm.6779.

Franklin GL. 1945. Preparation of thin sections of synthetic resins and wood-resin composites and a new macerating method for wood. Nature 155: 51. DOI: 10.1038/155051ao.

Gasson P. 2011. How precise can wood identification be? Wood anatomy's role in support of the legal timber trade, especially cites. IAWA J. 32: 137-154. DOI: 10.1163/22941932-900ooo49.

Gottwald H. 1984. Ebonies and persimmon. The economically important species of Diospyros. HolzZentralblatt 110: 1025-1027.

Gregory M. 1994. Bibliography of systematic wood anatomy of the dicotyledons. IAWA J. Suppl. 1: 265.

Grubben GJ. 2004. Vegetables. Plant resources of tropical Africa, series 2, p. 667. PROTA, Wageningen, Netherlands.

Hirschberger P. 2008. Illegal wood for the European market: an analysis of the EU import and export of illegal wood and related products. WWF, Frankfurt am Main.

Hoare A. 2015. Tackling illegal logging and related trade: what progress and where next? Available online at: https://www.chathamhouse.org/publication/tackling-illegal-logging-and-related-tradewhat-progress-and-where-next (accessed 22 September 2020).

IAWA Committee. 1989. IAWA list of microscopic features for hardwood identification. IAWA Bull. n.s. 10: $219-332$.

InsideWood. 2004-onwards. Published on the internet. Available online at: http://insidewood.lib. ncsu.edu/search (accessed 24 June 2020).

Irwin A. 2019. Tree sleuths are using DNA tests and machine vision to crack timber crimes. Nature 568: 19-21. DOI: 10.1038/d41586-019-01035-7.

Janssonius HH, Moll JW. 1926. Mikrographie des Holzes der auf Java vorkommenden Baumarten. Brill Archive.

Kanehira R. 1921. Anatomical characters and identification of Formosan woods with critical remarks from the climatic point of view. Bur. Product. Indust., Taihoku (Taiwan).

Kanehira R. 1924. Identification of Philippine woods by anatomical characters. 73 pp. Govt. Res. Inst., Taihoku, Formosa.

Koch G, Haag V. 2015. Control of internationally traded timber - the role of macroscopic and microscopic wood identification against illegal logging. J. Forensic Res. o6: 6. DOI: 10.4172/2157-7145. 1000317.

Koch G, Richter H-G, Schmitt U. 2011. Design and application of CITESwoodID computer-aided identification and description of CITES-protected timbers. IAWA J. 32: 213-220. DOI: 10.1163/22941932$9000005^{2}$. 
Lancaster C, Espinoza E. 2012. Analysis of select Dalbergia and trade timber using direct analysis in real-time and time-of-flight mass spectrometry for CITES enforcement. Rapid Commun. Mass Spectrom. 26: 1147-1156. DOI: 10.1002/rcm.6215.

Larson DA, Walker JF, Vargas OM, Smith SA. 2020. A consensus phylogenomic approach highlights paleopolyploid and rapid radiation in the history of Ericales. Am. J. Bot. 107: 773-789. DOI: 10. $1002 / a j b 2.1469$.

Lens F. 2005. Systematic significance of wood anatomical characters in Ericales. PhD Thesis. Laboratorium voor Systematiek, KU Leuven, Leuven.

Lens F, Baas P, Jansen S, Smets E. 2007. A search for phylogenetically informative wood characters within Lecythidaceae s.l. Am. J. Bot. 94: 483-502. DOI: 10.3732/ajb.94.4.483.

Lens F, Dressler S, Jansen S, van Evelghem L, Smets E. 2005. Relationships within balsaminoid Ericales: a wood anatomical approach. Am. J. Bot. 92: 941-953. DOI: 10.3732/ajb.92.6.941.

Lens F, Vos RA, Charrier G, van der Niet T, MerckxV, Baas P, et al. 2o16. Scalariform-to-simple transition in vessel perforation plates triggered by differences in climate during the evolution of Adoxaceae. Ann. Bot. 118: 1043-1056. DOI: 10.1093/aob/mcw151.

Linan AG, Schatz GE, Lowry PP, Miller A, Edwards CE. 2019. Ebony and the Mascarenes: the evolutionary relationships and biogeography of Diospyros (Ebenaceae) in the western Indian Ocean. Botan. J. Linn. Soc. 19o: 359-373. DOI: 10.1093/botlinnean/bozo34.

Madagascar Catalogue. 2012. Catalogue of the vascular plants of Madagascar. St Louis, MO: Missouri Botanical Garden; Antananarivo, Madagascar: Missouri Botanical Garden, Madagascar Research and Conservation Program. Available online at: http://www.efloras.org/madagascar (accessed 22 September 2020).

Mason J. 2019. Malagasy precious hardwoods: scientific and technical assessment to meet CITES objectives. The World Bank, Washington, DC.

McClure PJ, Chavarria GD, Espinoza E. 2015. Metabolic chemotypes of CITES protected Dalbergia timbers from Africa, Madagascar, and Asia. Rapid Commun. Mass Spectrom. 29: 783-788. DOI: $10.1002 / \mathrm{rcm} .7163$.

Meade A, Pagel M. 2016. BayesTraits V3 manual. University of Reading, Reading.

Metcalfe CR, Chalk L. 1950. Anatomy of the dicotyledons. 1 \& 2. Clarendon Press, Oxford.

Morton CM. 1994. The use of pollen morphology and wood anatomy in the study of the phylogeny of Ebenaceae and Rutaceae subtribe Cuspariinae. PhD Thesis, The City University of New York, New York, NY.

Nellemann CI. 2012. Green carbon, black trade: illegal logging, tax fraud, and laundering in the world's tropical forests. A rapid response assessment. Birkeland Trykkeri AS, Norway: United Nations Environment Programme, GRID-Arendal.

Normand D, Paquis J. 1976. Manuel d'identification des bois commerciaux. 2. Afrique guinéocongolaise. Centre Tech. For. Trop., Nogent-sur-Marne.

Panshin AJ, Zeeuw CD. 197o. Textbook of wood technology. Vol. 1. McGraw-Hill, New York, NY.

Pletsers A. 2006. Houtanatomie en pollenmorfologie van Ebenaceae. Master Thesis, Institute of Botany and Microbiology, KU Leuven, Leuven.

Pronk S. 20o8. Ecological wood anatomy in Diospyros (Ebenaceae, Ericales). Master Thesis, National Herbarium of The Netherlands, Leiden University branch, Leiden.

Rambaut A, Drummond AJ, Suchard M. 2014. Tracer vı. 6 http://beast.bio.ed.ac.uk. Tracer (Online 2015, 29 May).

Ravaomanalina BH, Crivellaro A, Schweingruber FH. 2017. Stem anatomy of Dalbergia and Diospyros species from Madagascar: with a special focus on wood identification. Springer, Berlin.

Record SJ. 1943. Timbers of the new world. Nature 152: 6o2. DOI: 10.1038/1526o2do.

Richter HG. 200o. Commercial timbers: descriptions, illustrations, identification, and information retrieval. Version 25 June 2009. Available online at: http://delta-intkey.com/wood/index.htm. 
Richter HG, Gembruch K, Koch G. 2014. CITESwoodID: descriptions, illustrations, identification, and information retrieval. English, French, German, and Spanish. Version: 19th February.

Rose JP, Kleist TJ, Löfstrand SD, Drew BT, Schönenberger J, Sytsma KJ. 2018. Phylogeny, historical biogeography, and diversification of angiosperm order Ericales suggest ancient Neotropical and East Asian connections. Mol. Phylogenet. Evol. 122: 59-79. DOI: 10.1016/j.ympev.2018.01.014.

Samuel R, Turner B, Duangjai S, Munzinger J, Paun O, Barfuss MHJ, et al. 2019. Systematics and evolution of the Old World Ebenaceae, a review with emphasis on the large genus Diospyros and its radiation in New Caledonia. Botan. J. Linn. Soc. 189: 99-114. DOI: 10.1093/botlinnean/boyo81.

Schatz GE, Lowry PP. 2018. Taxonomic studies of Diospyros (Ebenaceae) from the Malagasy region. III. New species from the island of Nosy Mangabe in the Bay of Antongil. Novon: A Journal for Botanical Nomenclature 26: 272-286. DOI: 10.3417/2018209.

Schmitz N, Boner M, Cervera MT, Chavesta M, Cronn R, Degen B, et al. 2019. General sampling guide for timber tracking. Global Timber Tracking Network, GTTN Secretariat, European Forest Institute, Joensuu, and Thuenen Institute, Hamburg. 46 p.

Tacconi L, Cerutti PO, Leipold S, Rodrigues RJ, Savaresi A, To P, Weng X. 2016. Defining illegal forest activities and illegal logging. In: Kleinschmit D, Mansourian S, Wildburger C, Purret A (eds.), Illegal logging and related timber trade — dimensions, drivers, impacts and responses: $23-36$. International Union of Forest Research Organizations (IUFRO), Vienna.

UNODC. 2016. Best practice guide for forensic timber identification. In: United Nations office on drugs and crime: international consortium on combating wildlife crime. Laboratory and Scientific Section, Global Programme for Combating Wildlife and Forest Crime, Vienna.

Van Den Brink RC. 1936. Revisio Ebenacearum Malayensium. Revisio Ebenacearum Malayensium.

Wallnöfer B. 2001. The biology and systematics of Ebenaceae: a review. In: Annalen des Naturhistorischen Museums in Wien. Serie B für Botanik und Zoologie: $485^{-512}$.

Wallnöfer B. 20o6. A revision of Neotropical Diospyros (Ebenaceae): part 1. In: Annalen des Naturhistorischen Museums in Wien. Serie B für Botanik und Zoologie: 207-247.

Wallnöfer B. 20o8. A revision of Neotropical Diospyros (Ebenaceae): part 2. In: Annalen des Naturhistorischen Museums in Wien. Serie B für Botanik und Zoologie: 173-211.

Wallnöfer B. 2009. A revision of Neotropical Diospyros (Ebenaceae): part 3. In: Annalen des Naturhistorischen Museums in Wien. Serie B für Botanik und Zoologie: 101-133.

Wallnöfer B. 2010. A revision of Neotropical Diospyros (Ebenaceae): part 4. In: Annalen des Naturhistorischen Museums in Wien. Serie B für Botanik und Zoologie: 181-220.

Wallnöfer B. 2012. A revision of Neotropical Diospyros (Ebenaceae): part 5. In: Annalen des Naturhistorischen Museums in Wien. Serie B für Botanik und Zoologie: 223-251.

Wallnöfer B. 2013. A revision of Neotropical Diospyros (Ebenaceae): part 6. In: Annalen des Naturhistorischen Museums in Wien. Serie B für Botanik und Zoologie: 219-235.

Wallnöfer B. 2014. A revision of Neotropical Diospyros (Ebenaceae): part 7. In: Annalen des Naturhistorischen Museums in Wien. Serie B für Botanik und Zoologie: 153-179.

Wallnöfer B. 2016. A revision of Neotropical Diospyros (Ebenaceae): part 9. In: Annalen des Naturhistorischen Museums in Wien. Serie B für Botanik und Zoologie: 79-114.

Wallnöfer B. 2017. A revision of Neotropical Diospyros (Ebenaceae) part 10. In: Annalen des Naturhistorischen Museums in Wien. Serie B für Botanik und Zoologie 119: 183-226.

Wallnöfer B. 2018. A revision of Neotropical Diospyros (Ebenaceae) part 11. In: Annalen des Naturhistorischen Museums in Wien. Serie B für Botanik und Zoologie 120: 145-226.

Wallnöfer B. 2019. A revision of Neotropical Diospyros (Ebenaceae). In: Annalen des Naturhistorischen Museums in Wien. Serie B für Botanik und Zoologie 121: 271-298.

Wheeler EA. 2011. Inside wood — a web resource for hardwood anatomy. IAWA J. 32: 199-211. DOI: 10. 1163/22941932-90000051.

White F, Verdcourt B. 1996. Ebenaceae, Polhill RM (ed.). Royal Botanic Gardens, London. 
Wickremasinghe BK, Heart TR. 20o6. A comparative wood anatomical study of the genus Diospyros L. (Ebenaceae) in Sri Lanka. Cey. J. Sci. (Bio. Sci.) 35: 115-136.

Yang Z, Kumar S, Nei M. 1995. A new method of inference of ancestral nucleotide and amino acid sequences. Genetics 141: 1641-165o.

Yao T. 1932-1933. Timber studies of Chinese trees I-IV. Bull. Fan Memorial Inst. Biol., Peking 3: 127-131.

Edited by Yafang Yin

\section{APPENDIX}

\section{Wood anatomical descriptions of Royena, Euclea and Lissocarpa}

Royena (based on R. glabra RBHw179o9, R. lucida Tw21536, R. lycioides RBHw3447 and R. pallens Tw28101)

Growth rings distinctly marked by relatively thick-walled latewood fibres. Wood diffuseporous. Vessels (12)-32-5o-(8o)/mm², usually in radial multiples of 2-6-(15), sometimes also clusters up to 12 vessels (Fig. A1A). Tangential diameter of vessels $35^{-85}-(100) \mu \mathrm{m}$, vessel elements 330-650-(1200) $\mu \mathrm{m}$ long. Vessel outline circular. Vessel perforation plates always simple. Intervessel pits typically alternate to opposite but the alternate type often dominates, intervessel pits $3-4 \mu \mathrm{m}$ in horizontal diameter but $4-7 \mu \mathrm{m}$ in Royena pallens. Vessel-ray pits opposite to alternate, distinctly bordered, $3-4 \mu \mathrm{m}$ in horizontal diameter. Helical thickenings absent. Tracheid absent. Fibres non-septate, with simple to minutely bordered pits concentrated in radial walls. Fibres 650-1200 $\mu \mathrm{m}$ long and usually thinwalled, but very thick-walled in Royena pallens. Apotracheal axial parenchyma mostly in interrupted bands of 1-2 cells wide to diffuse-in-aggregate, paratracheal parenchyma always in combination with scanty or scanty to vasicentric axial parenchyma, strands of 3-4-(8) cells. Uniseriate rays always present and often more frequent than multiseriate rays, $180-75^{\circ}-\left(145^{\circ}\right) \mu \mathrm{m}$ high, consisting of procumbent or square body ray cells, and 14 rows of upright marginal ray cells, with (2)-6-11-(14) rays/mm. Multiseriate rays $2-(3)-$ seriate, $250-1000 \mu \mathrm{m}$ high, consisting of mainly procumbent (sometimes square) body ray cells, and $1-4$ rows of upright marginal ray cells, $2-6(9)$ rays $/ \mathrm{mm}$. Sheath cells absent. Prismatic crystals common in non-chambered ray cells. Silica bodies present in ray cells (Fig. A1B).

Euclea (based on E. divinorum Tw28287, E. lanceolate Tw39136, E. natalensis RBHw17909 and E. schimperia $T W_{33} 870$ )

Growth rings absent but distinctly marked by relatively thick-walled latewood fibres in E. natalensis. Wood diffuse-porous. Tangential diameter of vessels (25)-6o-(110) $\mu \mathrm{m}$, vessel elements (200)-355-(480) $\mu \mathrm{m}$ long. Vessels (5)-18-(40)/ $\mathrm{mm}^{2}$, usually solitary or in radial multiples of $2-4$ (Fig. A1C). Vessel outline circular. Vessel perforation plates always simple. Intervessel pits typically alternate to opposite, intervessel pits $3-4 \mu \mathrm{m}$. Vessel-ray pits alternate to opposite, but the alternate type often dominates, distinctly bordered, $3-4 \mu \mathrm{m}$. Helical thickenings absent. Tracheids absent. Fibres non-septate, with simple to minutely bordered pits concentrated in radial walls. Fibres (700)-96o-(1280) $\mu \mathrm{m}$ long, thin- to thickwalled but very thick-walled in E. divinorum. Apotracheal axial parenchyma mostly in in- 


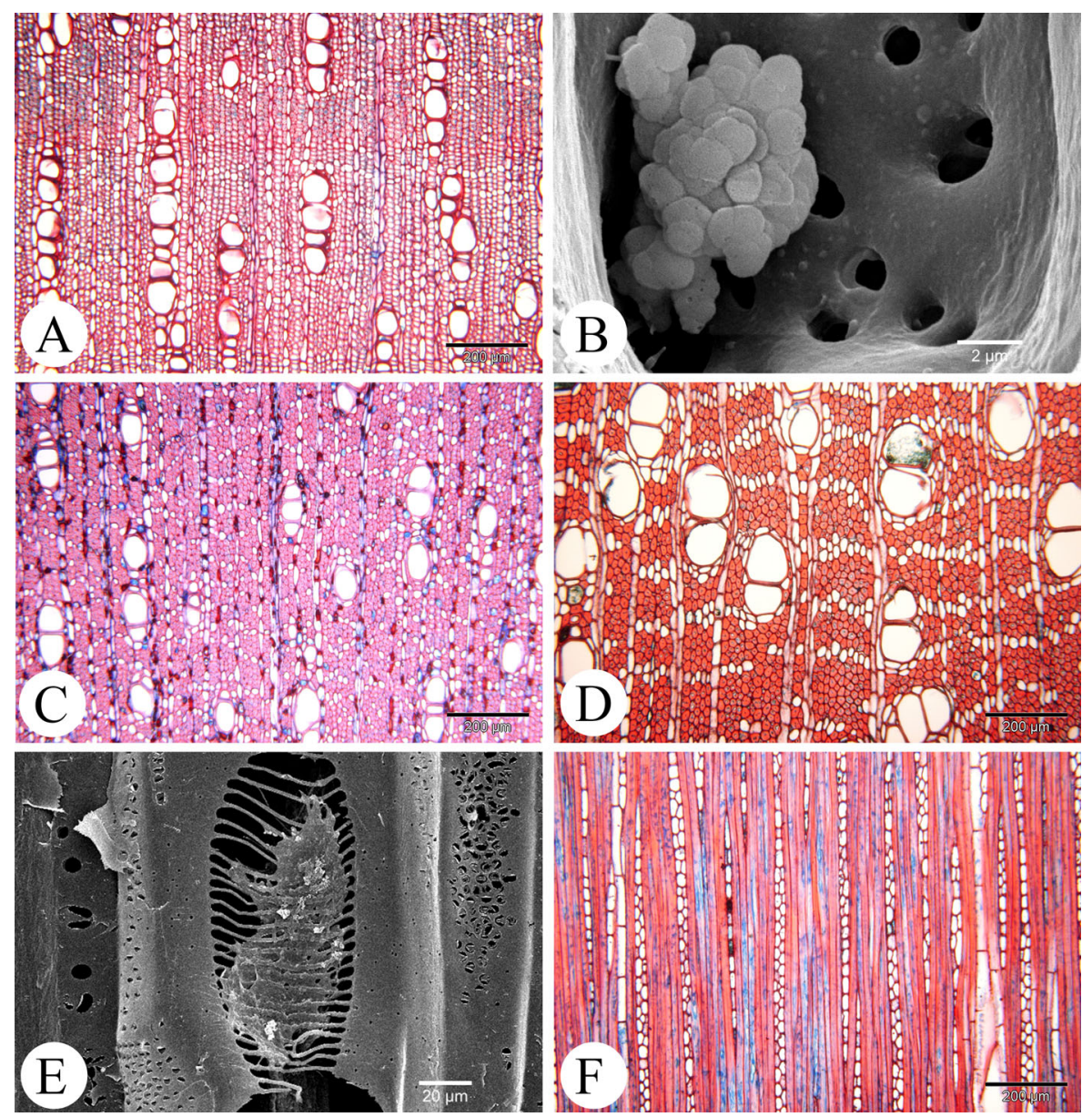

Figure A1. Wood anatomical sections of Euclea, Lissocarpa, and Royena. (A, B) Royena lucida, vessels in radial multiples (A), silica bodies (B). (C) Euclea divinorum, vessels solitary, or in short radial multiples. (D)-(F) Lissocarpa guianensis, vessels in short radial multiples (D), scalariform perforation plates $(\mathrm{E})$, long multiseriate rays $(\mathrm{F})$.

terrupted bands of 1-2 cells wide to diffuse-in-aggregates, paratracheal parenchyma scanty, strands of $3-5$ cells. Uniseriate and multiseriate rays always present, $\left(15^{\circ}\right)-365^{-}(1200) \mu \mathrm{m}$ high, consisting of procumbent or square body ray cells, and 1-4 rows of upright marginal ray cells, with 4-10 rays $/ \mathrm{mm}$. Multiseriate rays 2-(3)-seriate, (260)-500-(1300) $\mu \mathrm{m}$ high, consisting of mainly procumbent (sometimes square) body ray cells, and 1-4 rows of upright marginal ray cells, $3^{-7}$ rays $/ \mathrm{mm}$. Sheath cells absent. Prismatic crystals present in axial parenchyma and ray cells in E. schimperia, ray cells in E. lanceolate and in chambered axial parenchyma in E. natalensis, no mineral inclusion observed in E. divinorum. 


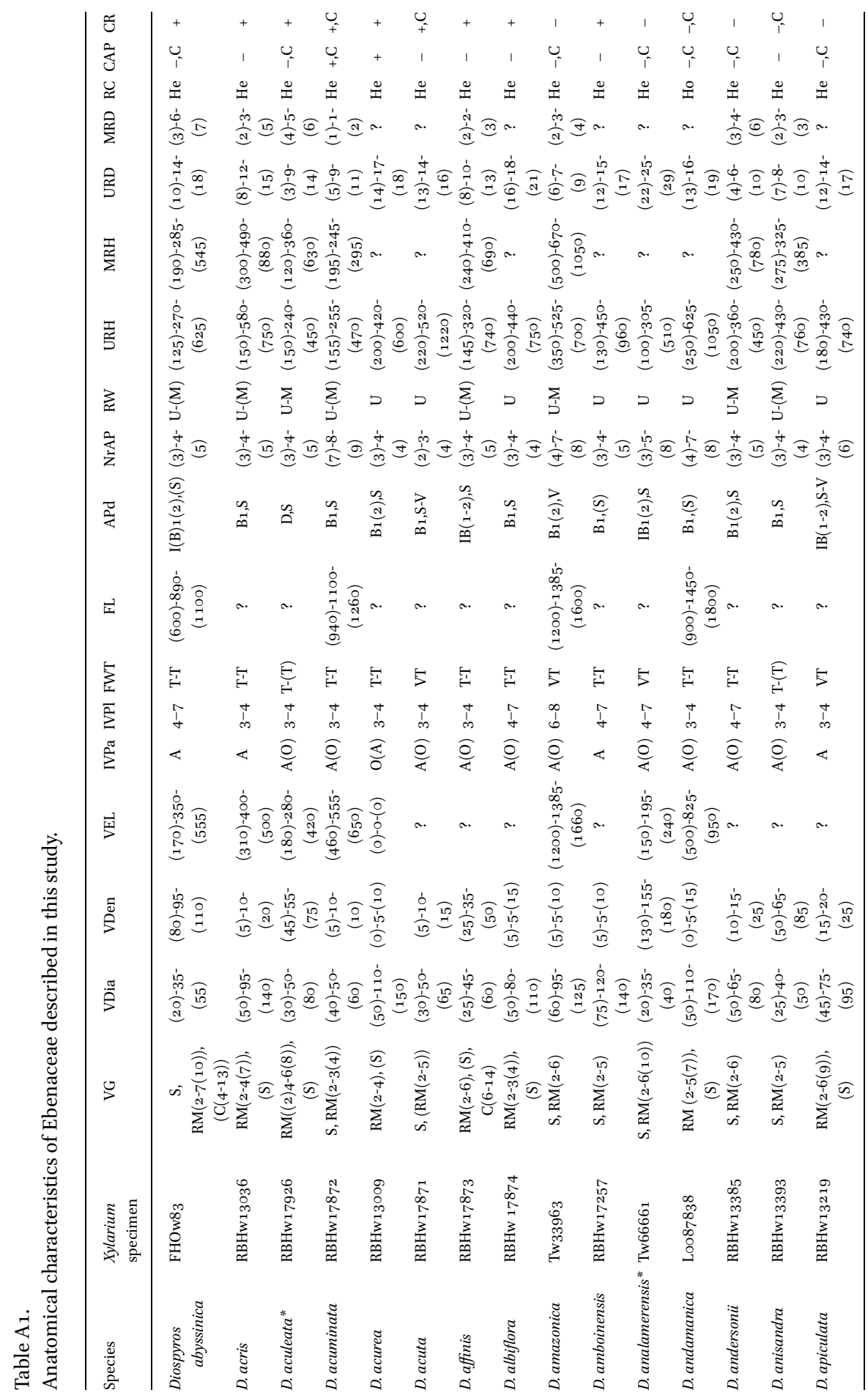




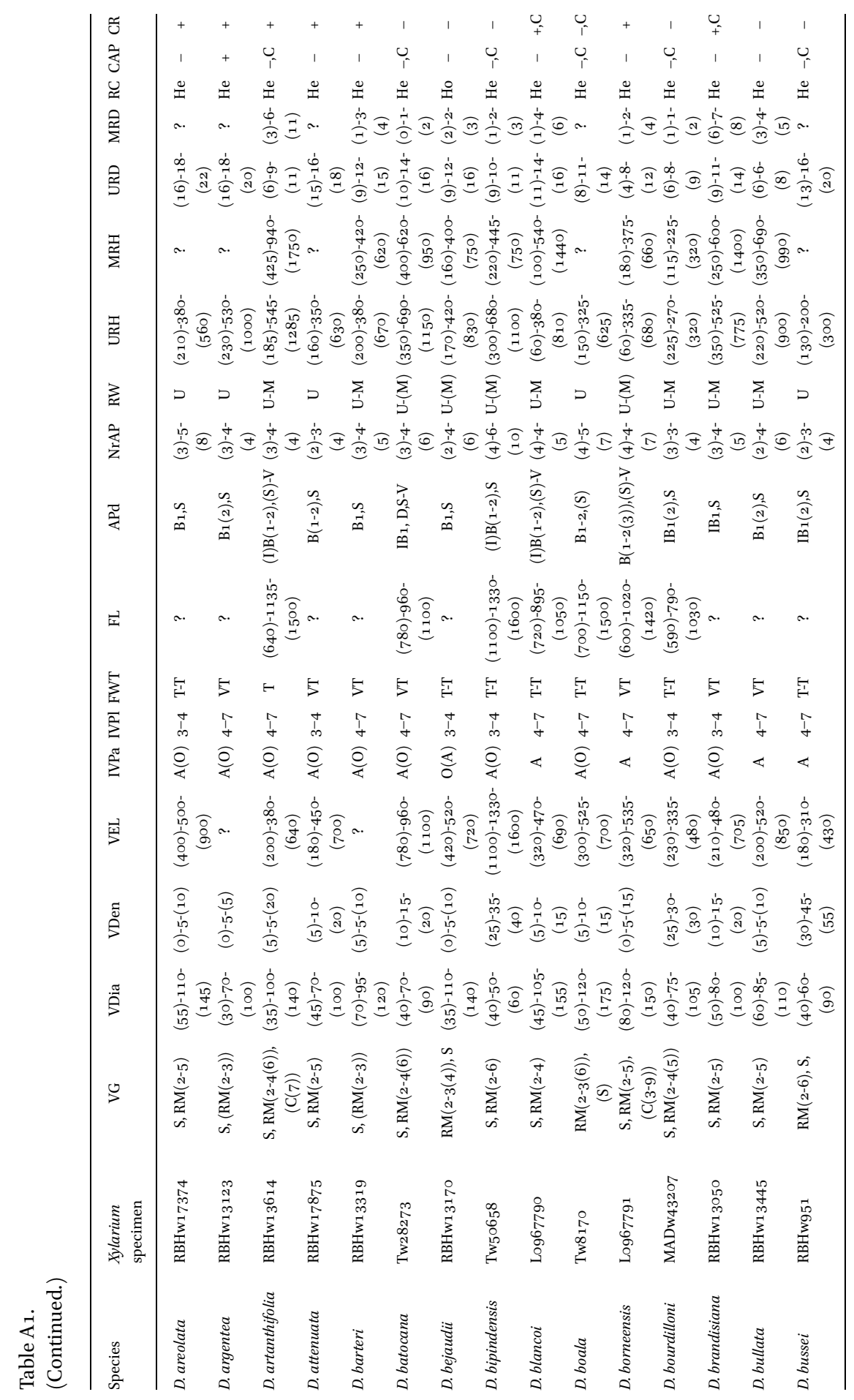




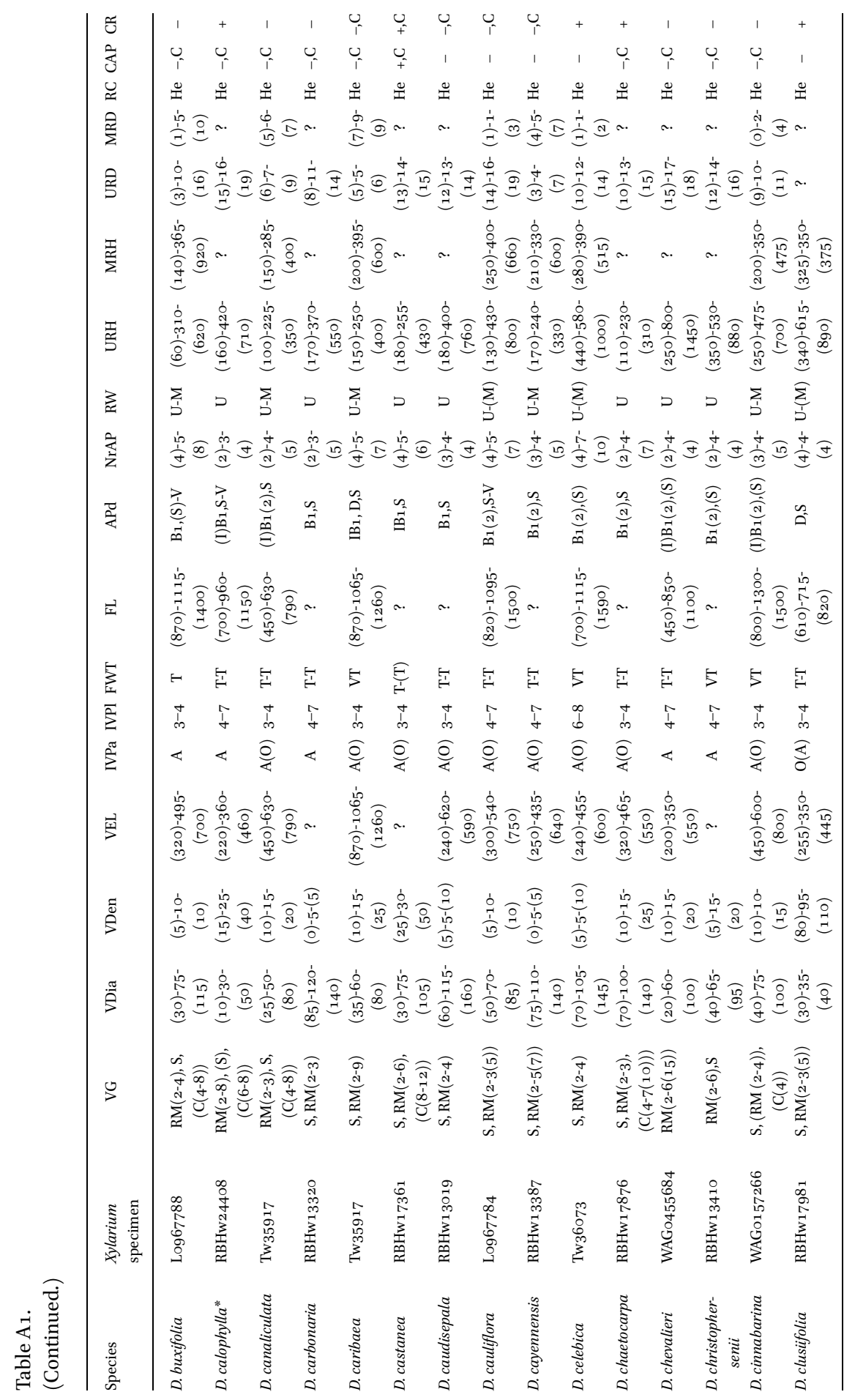




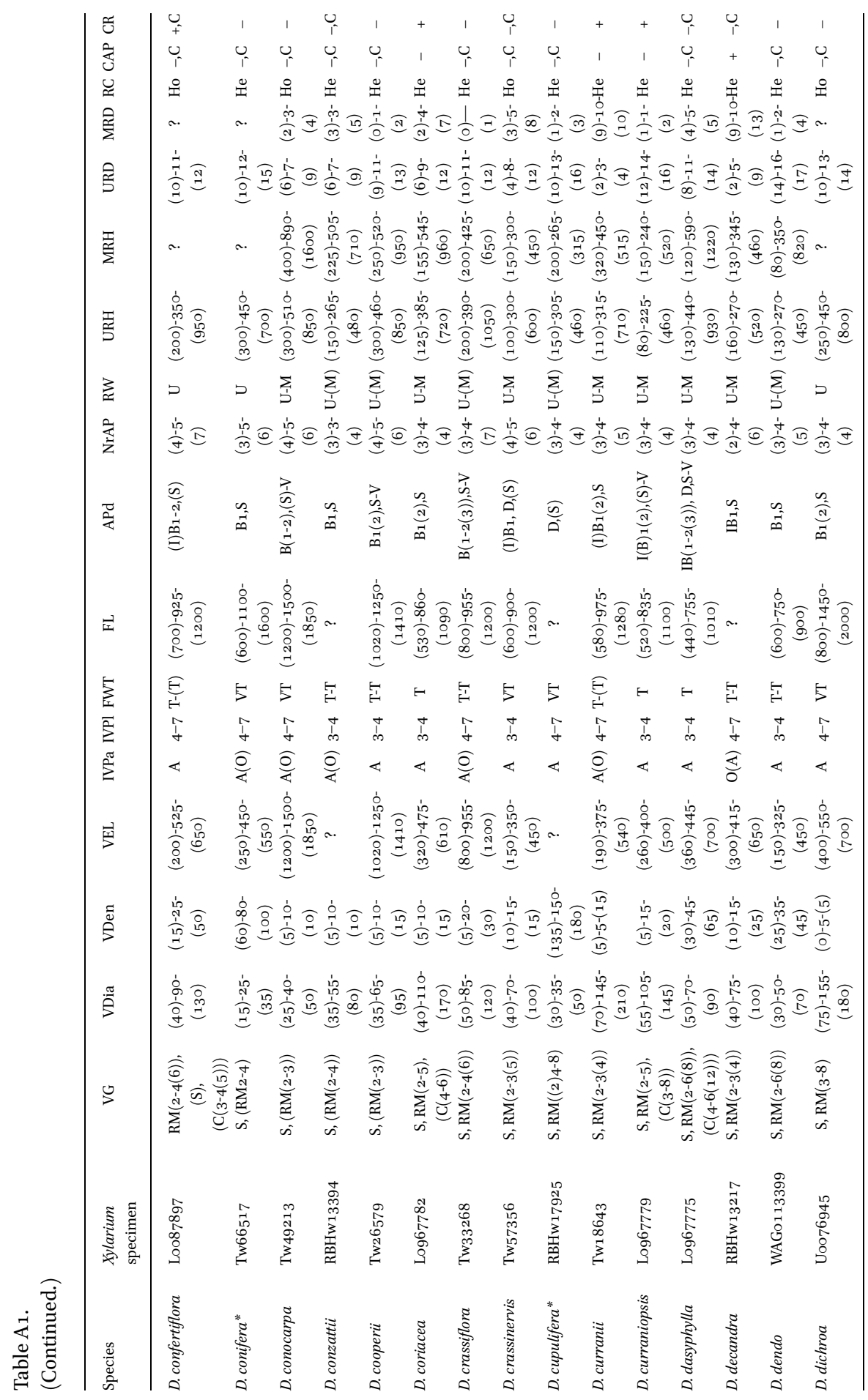




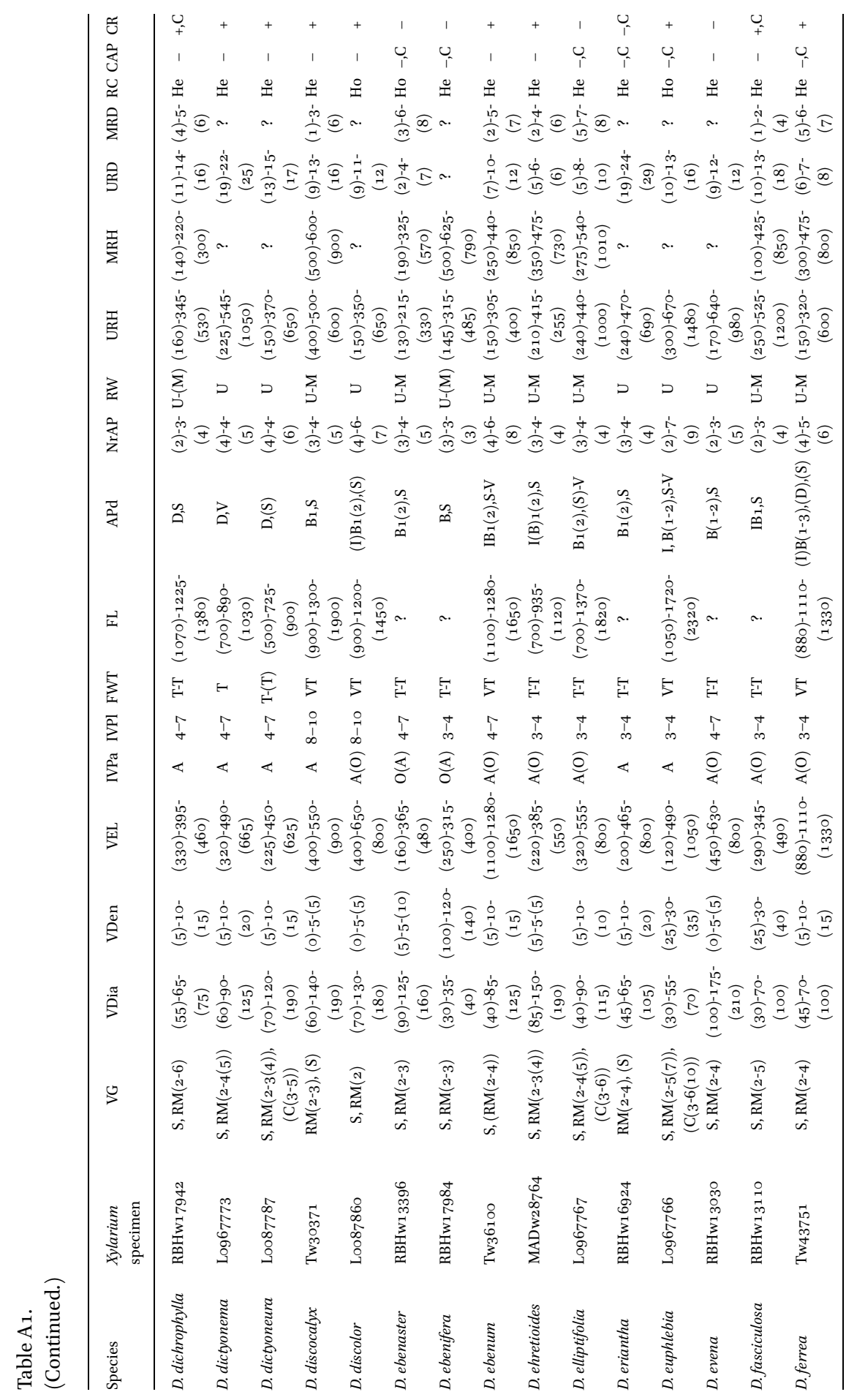




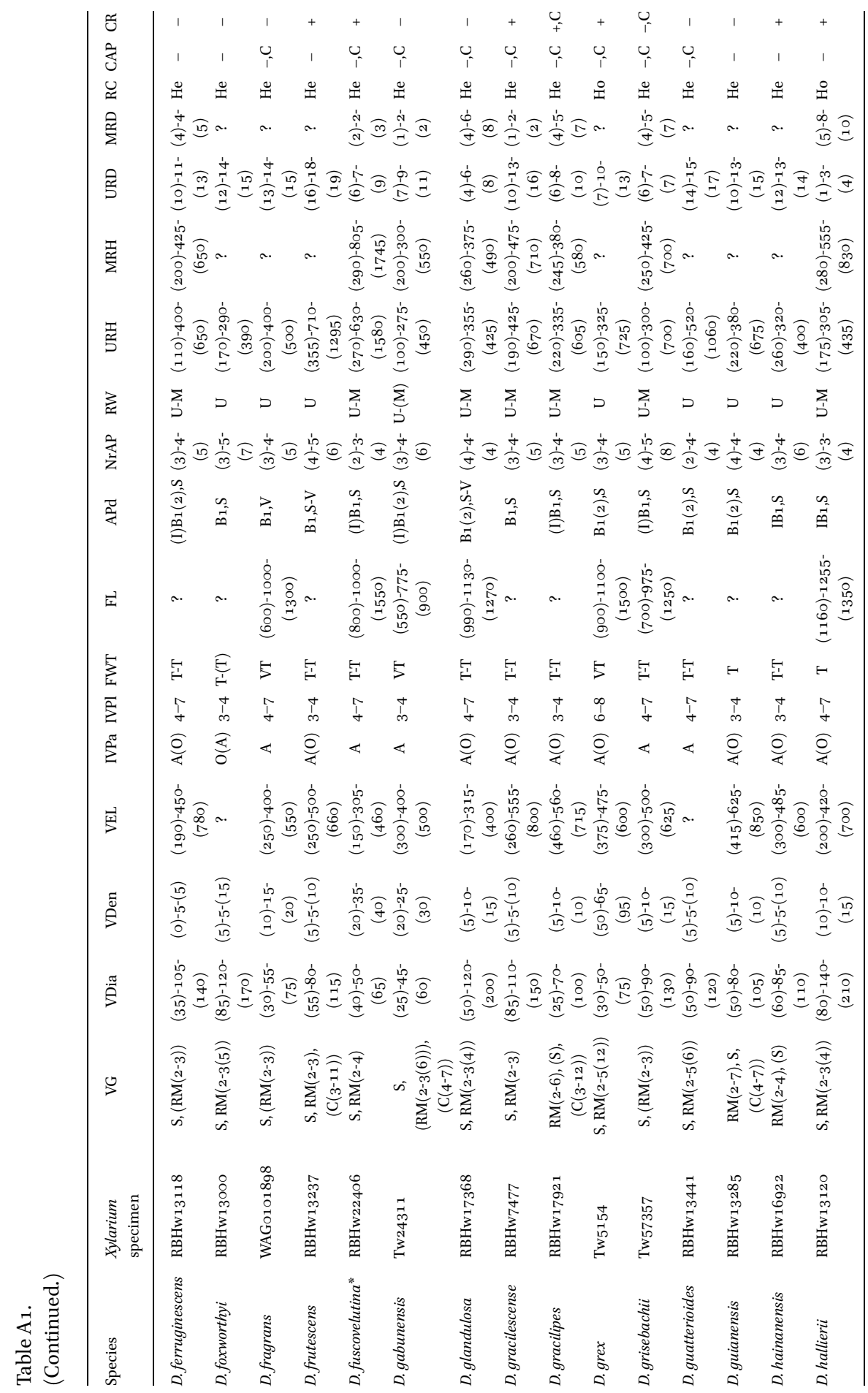




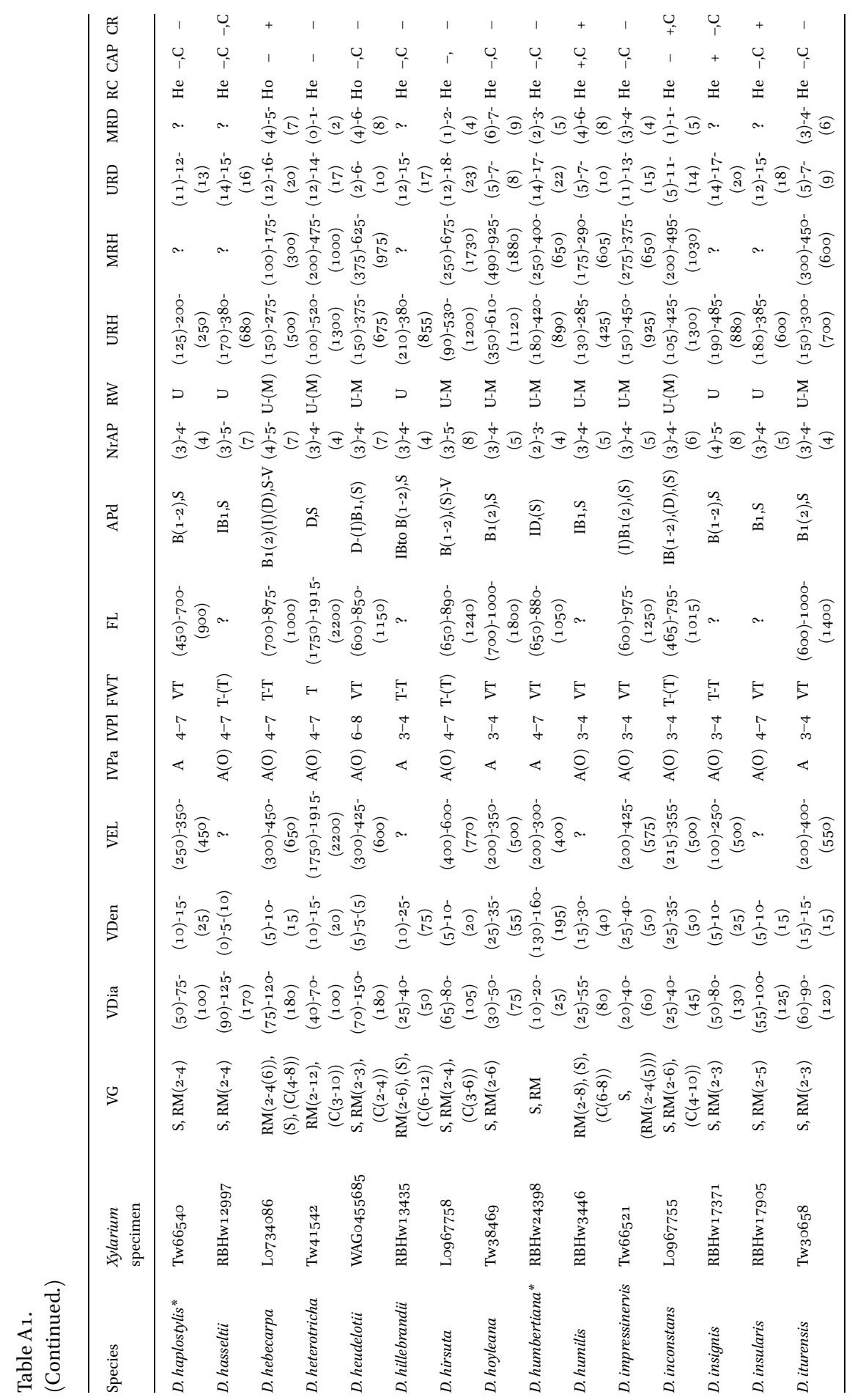




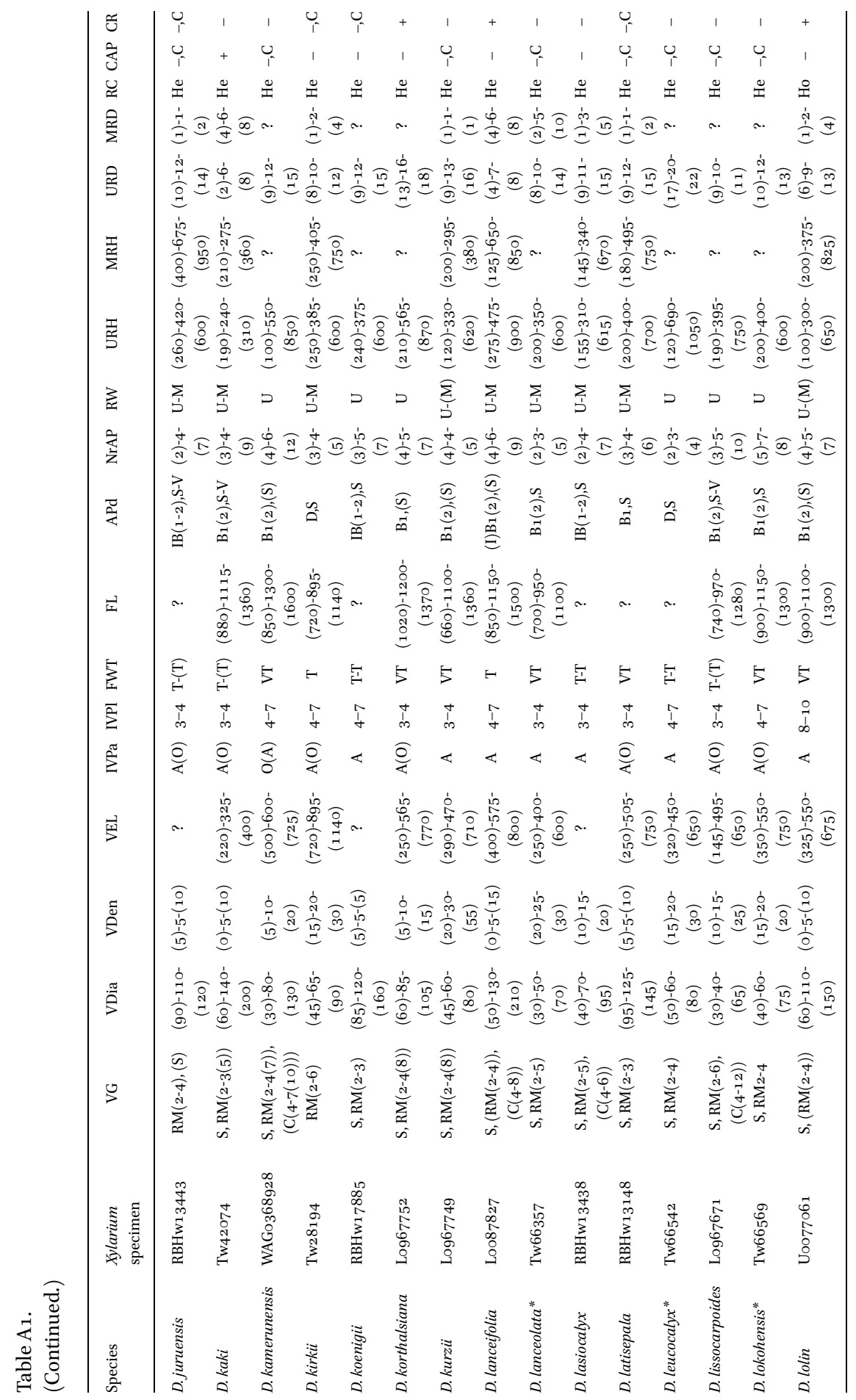




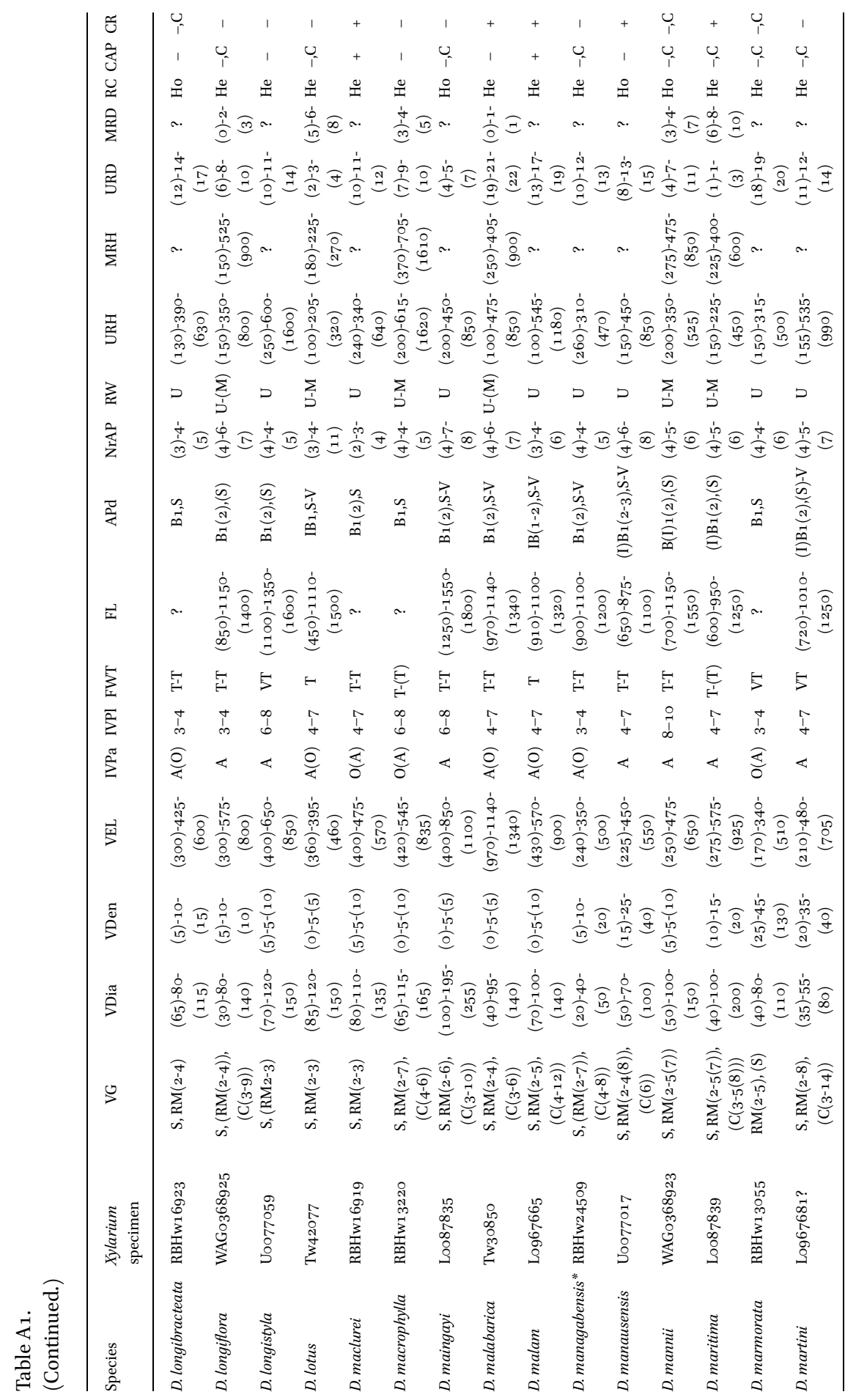




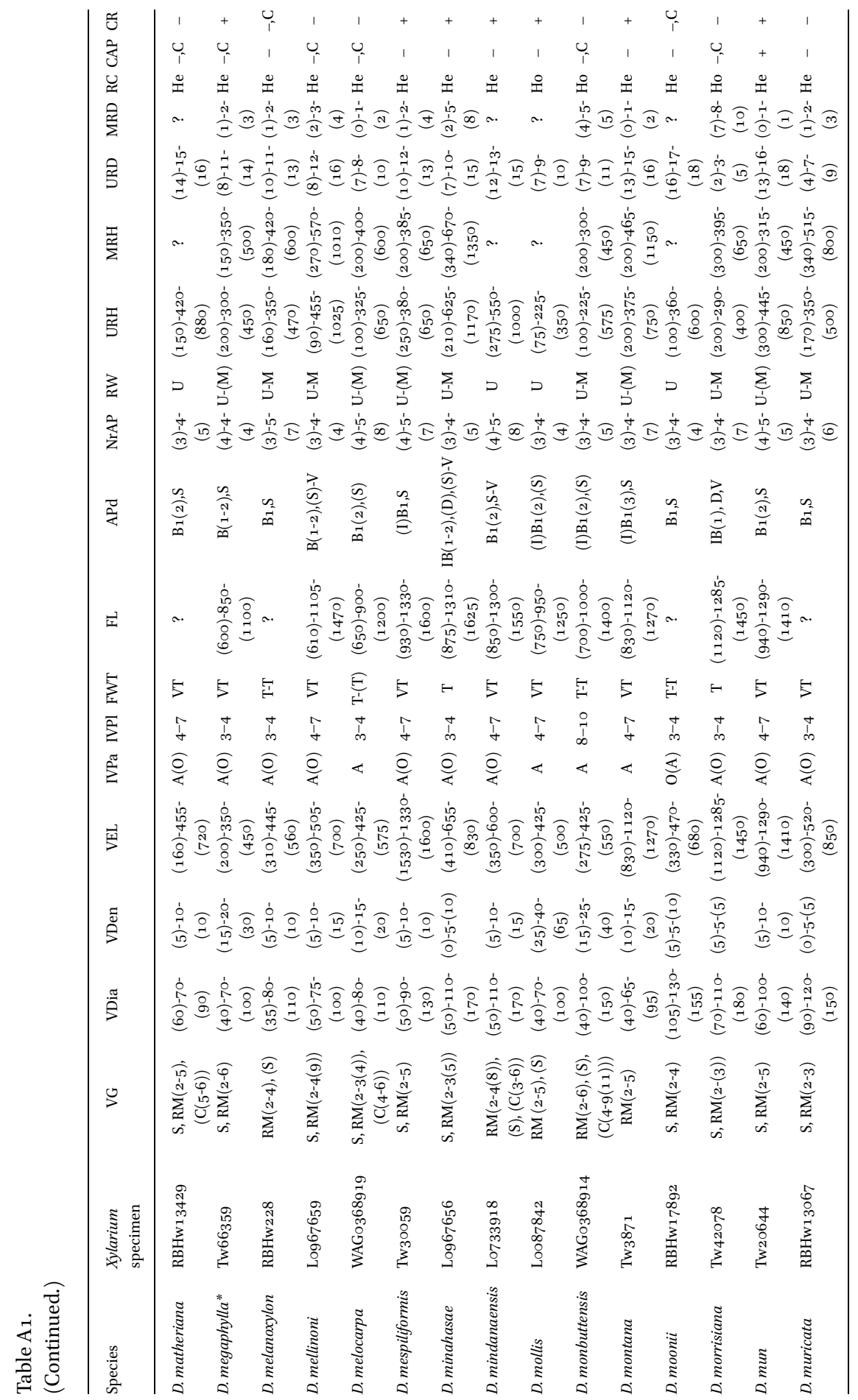




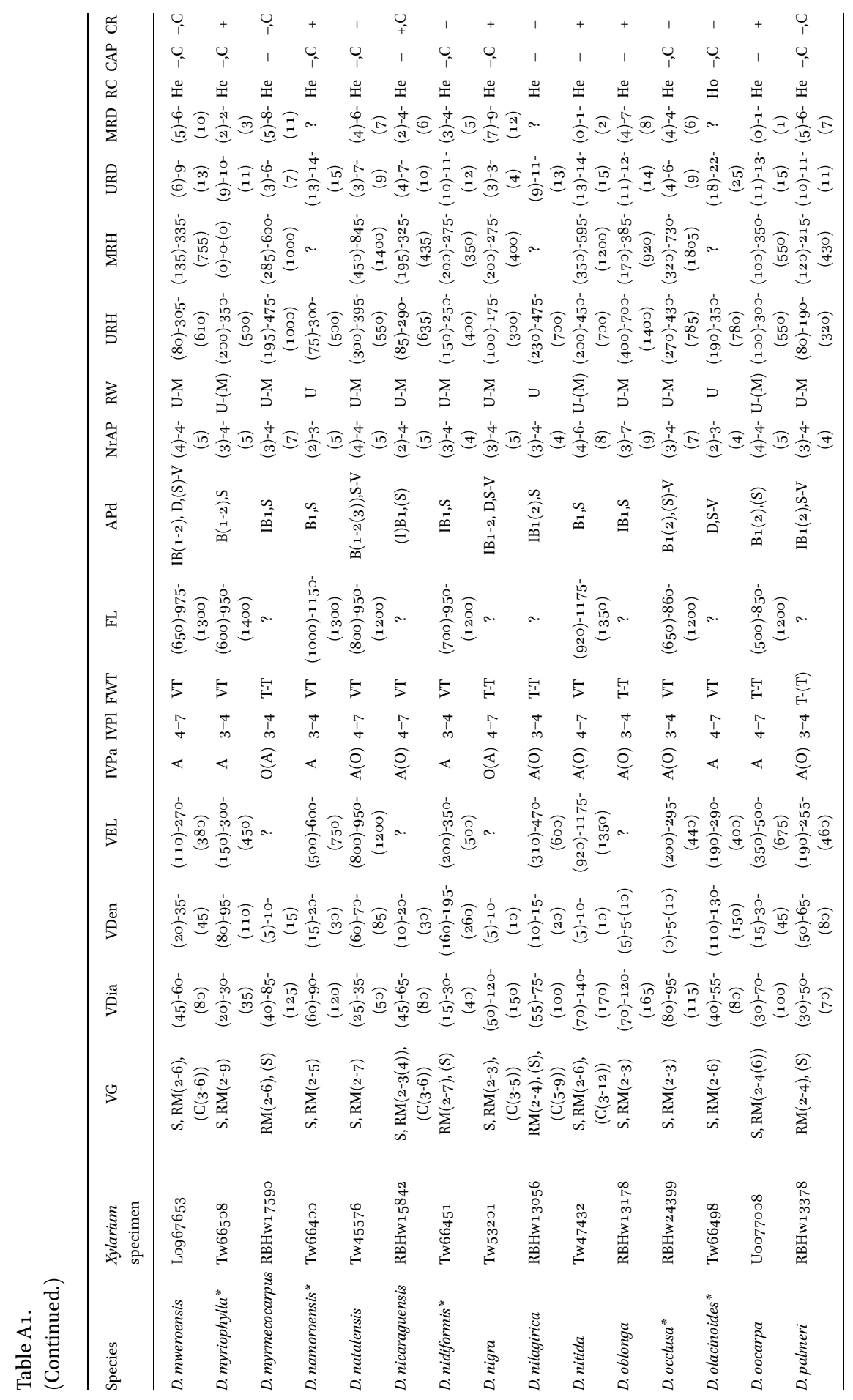




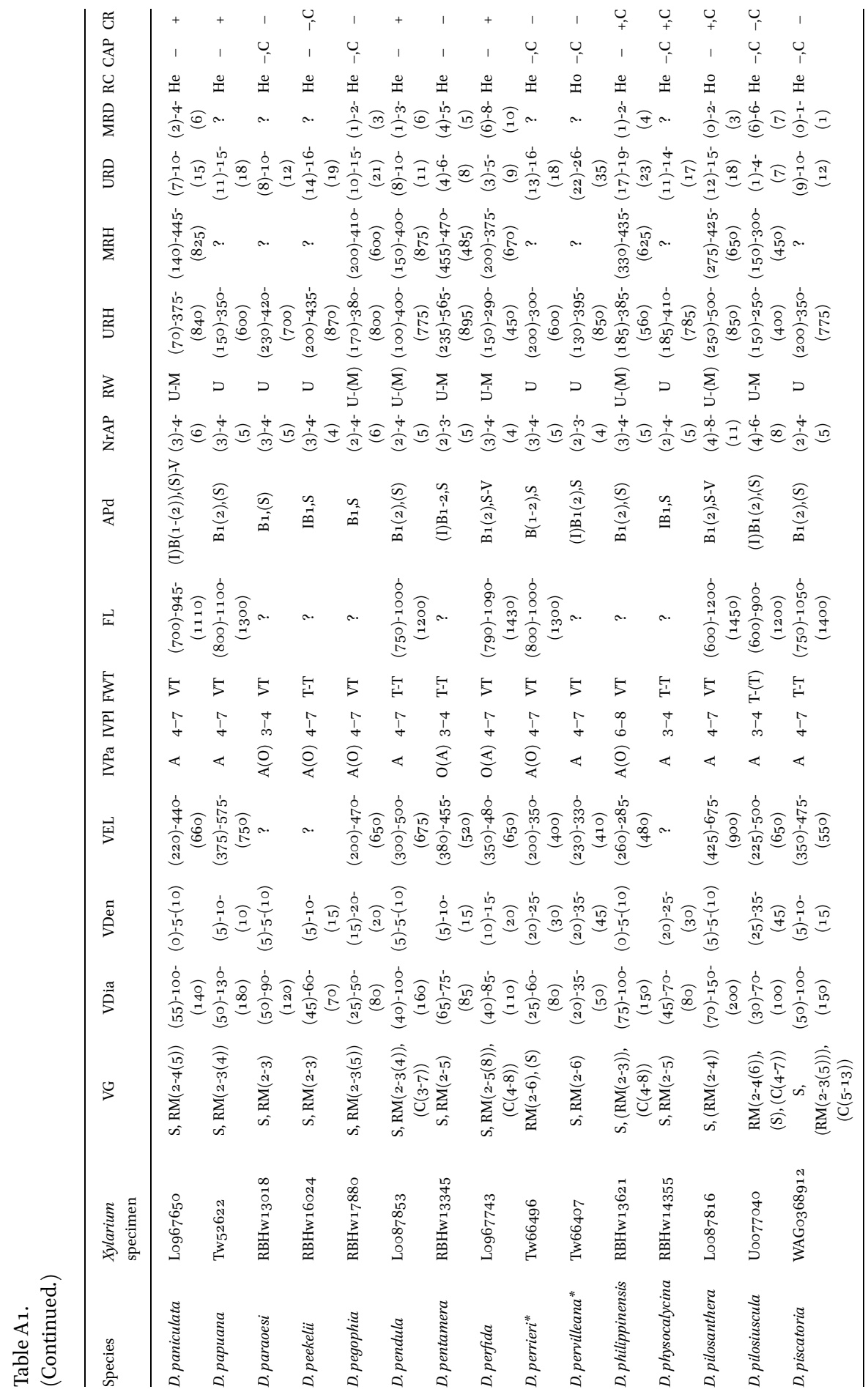




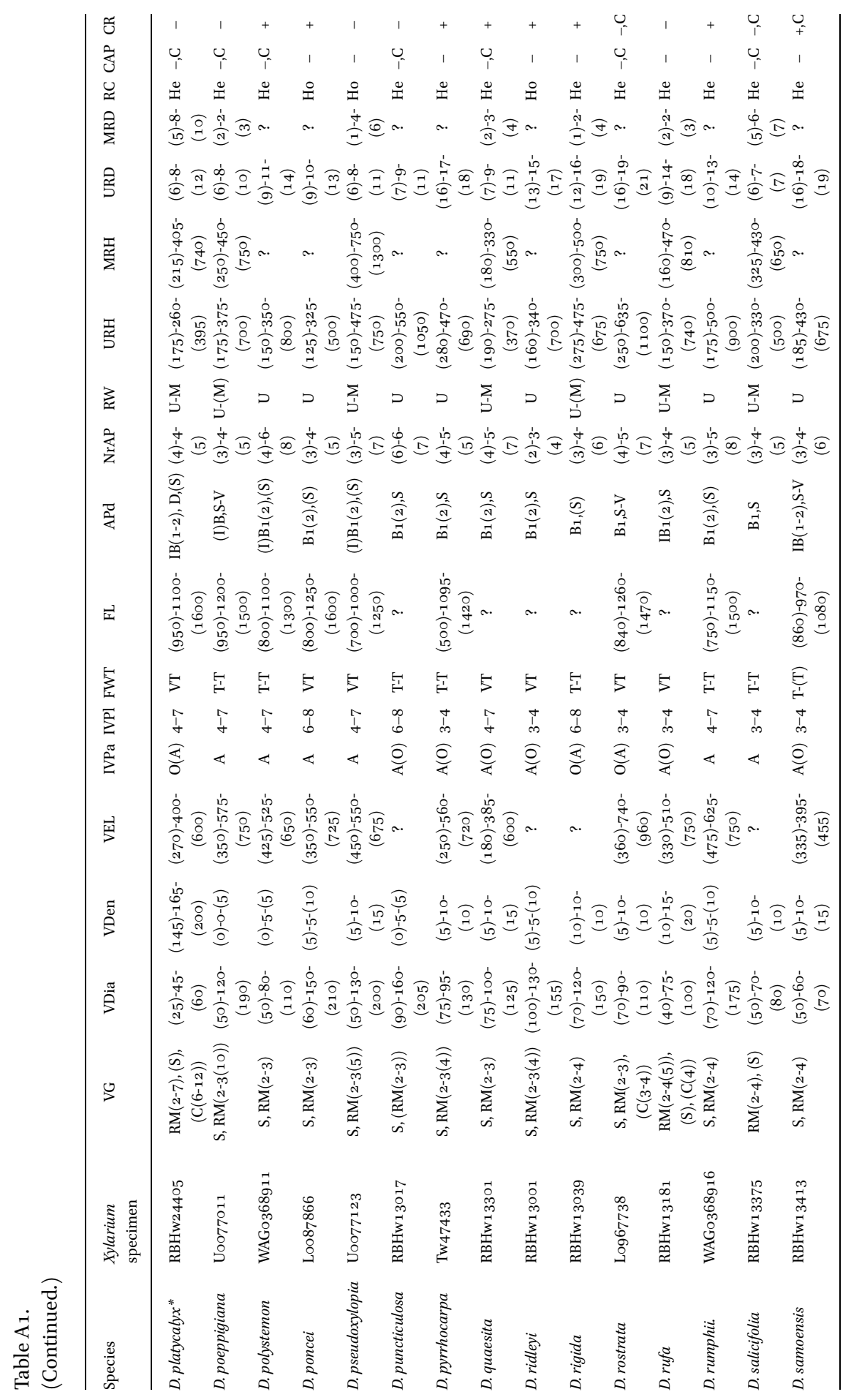




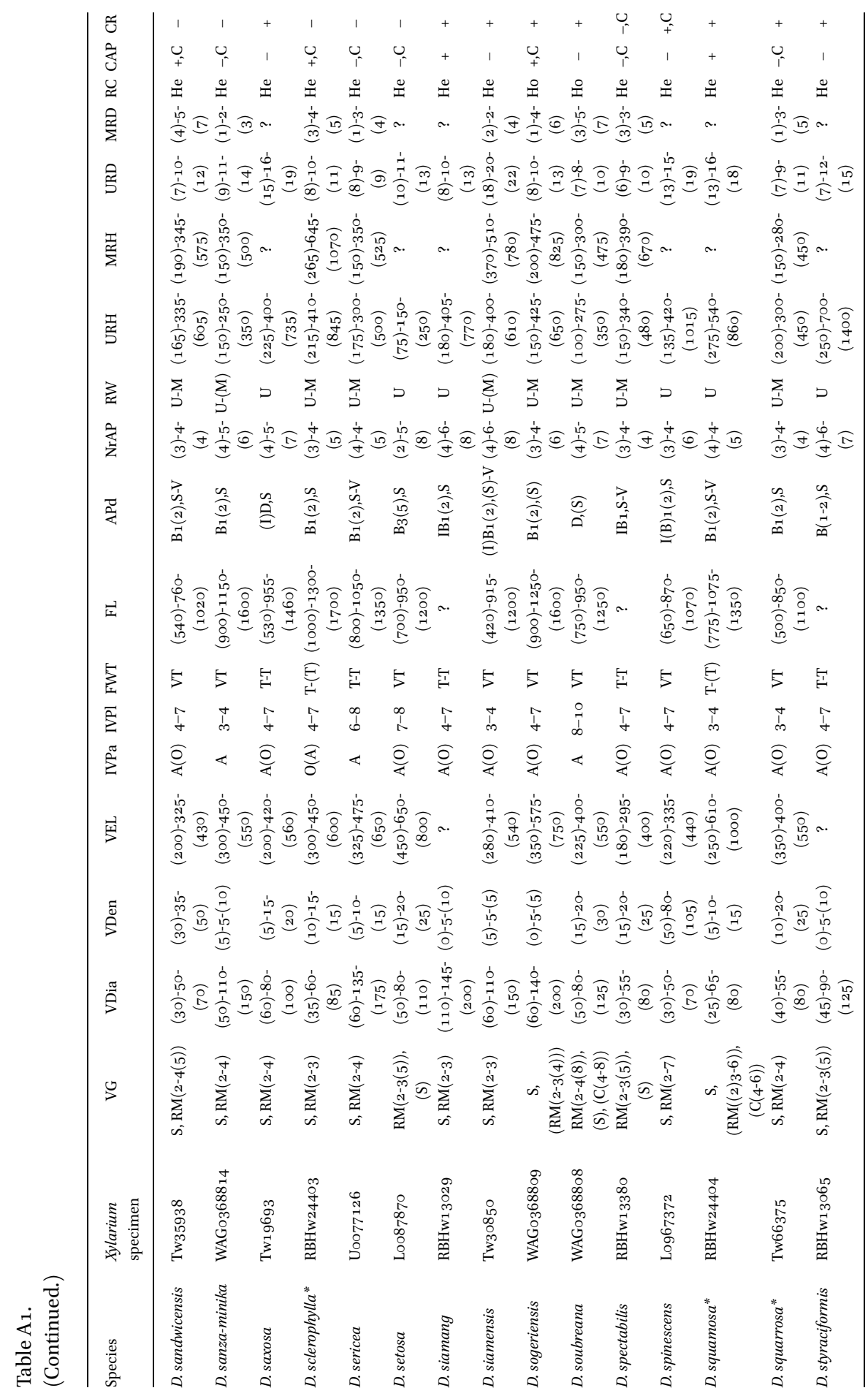




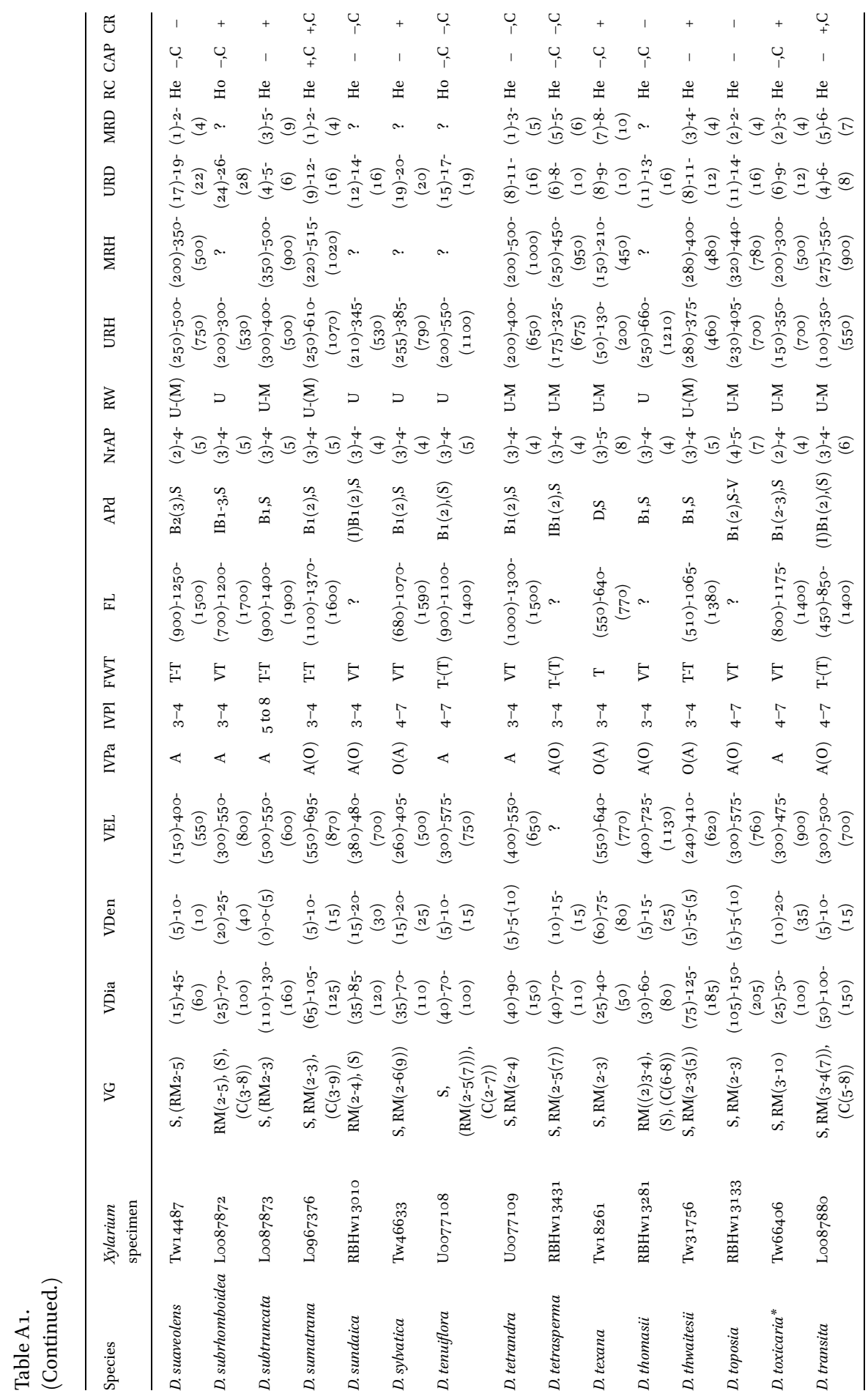




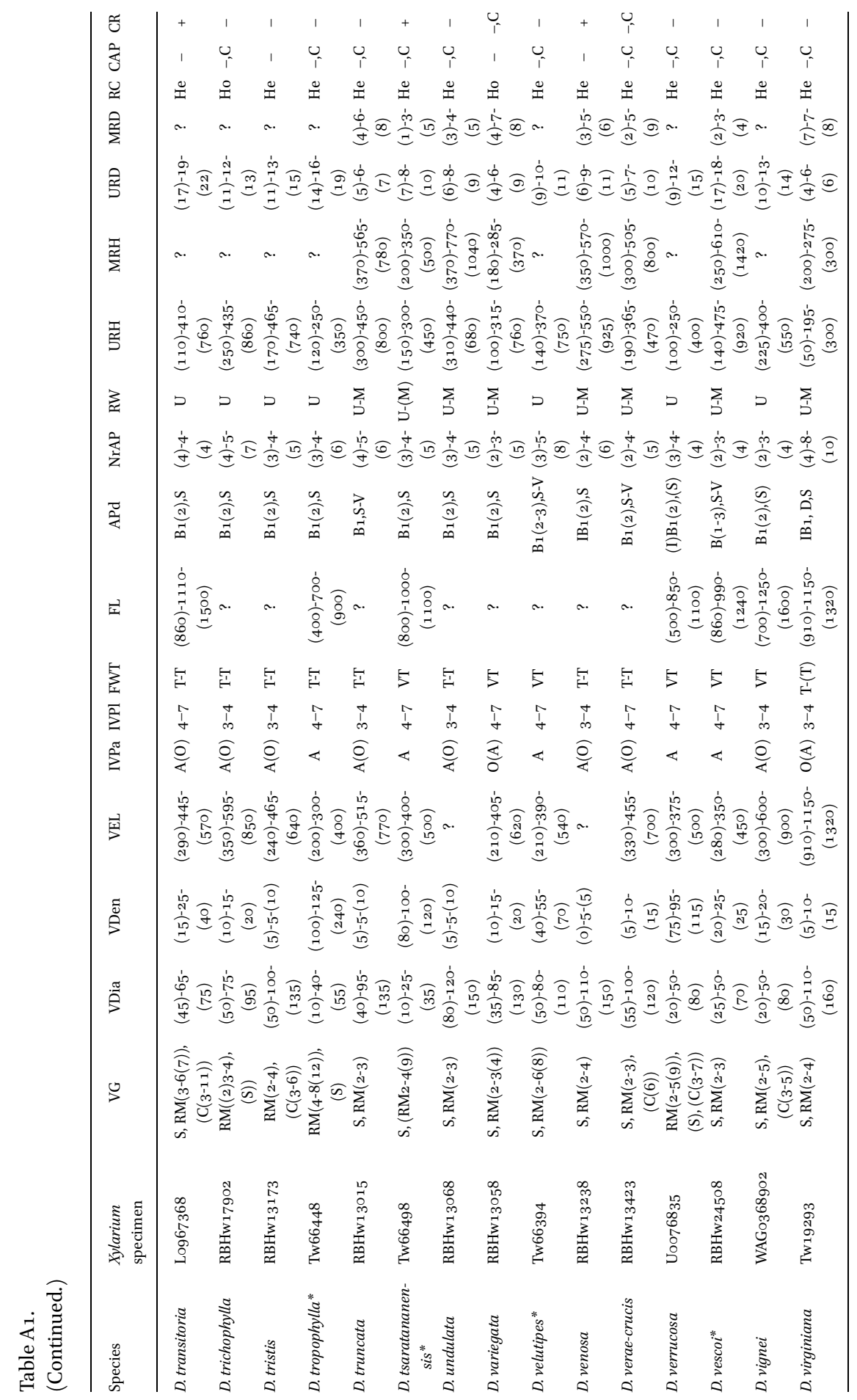




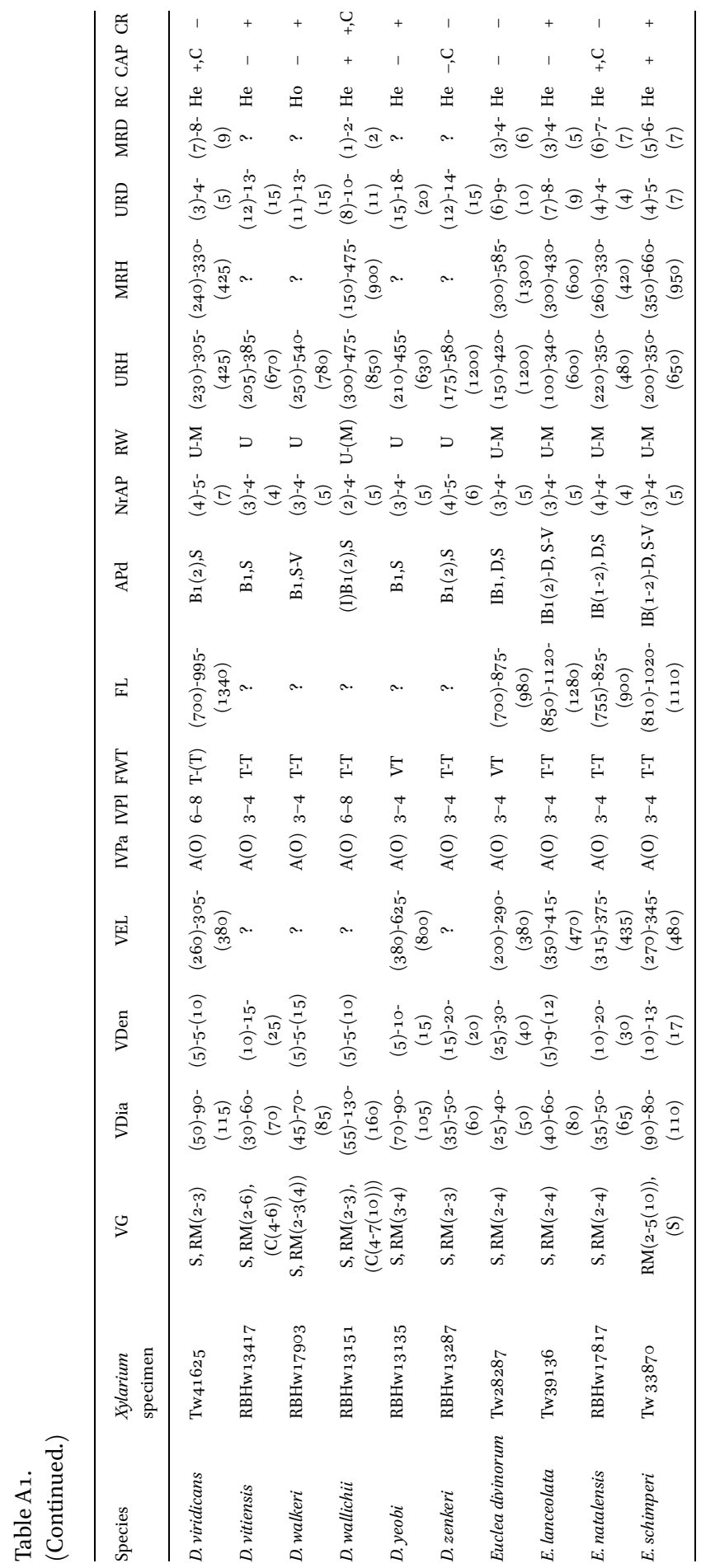




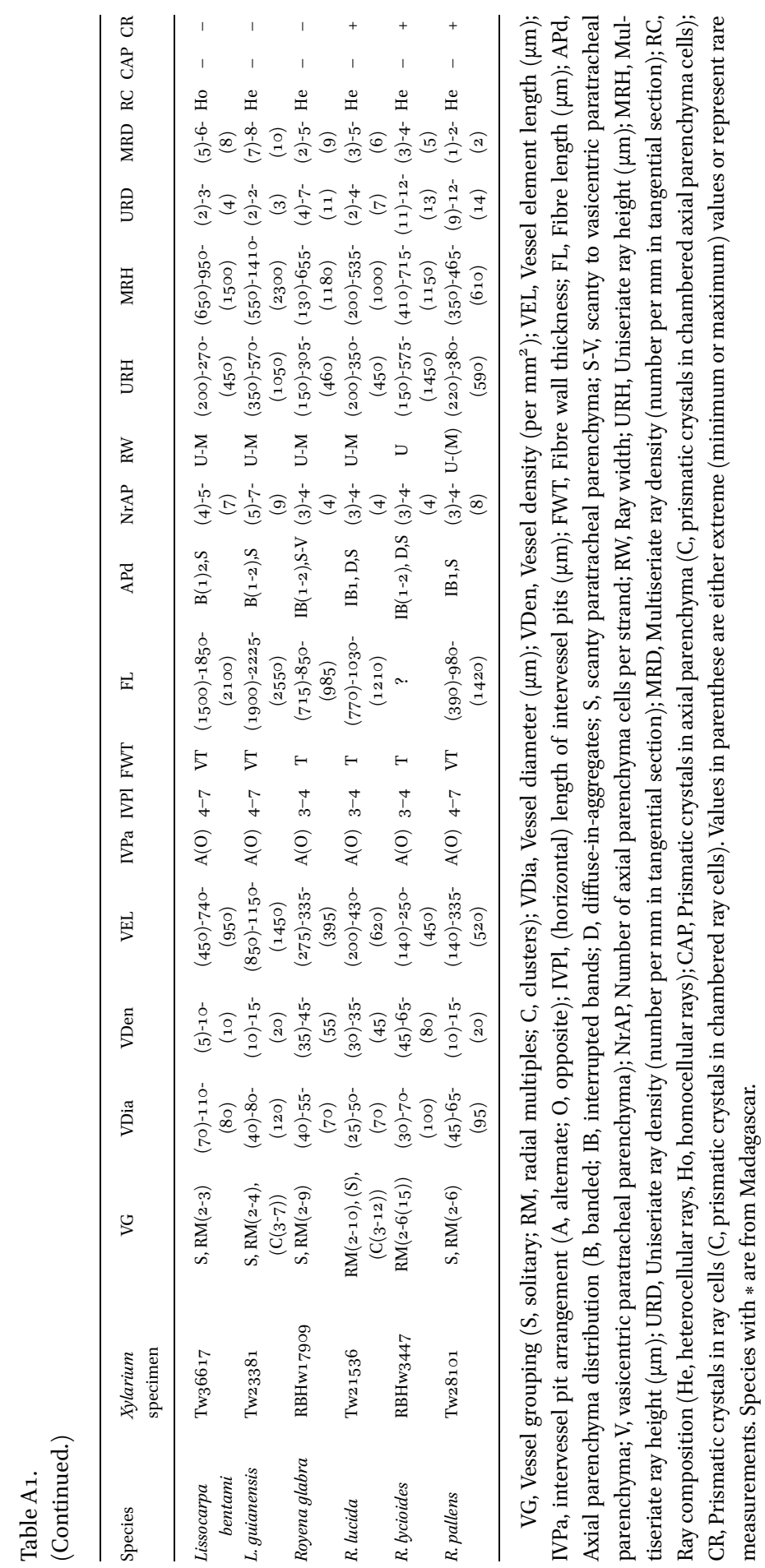



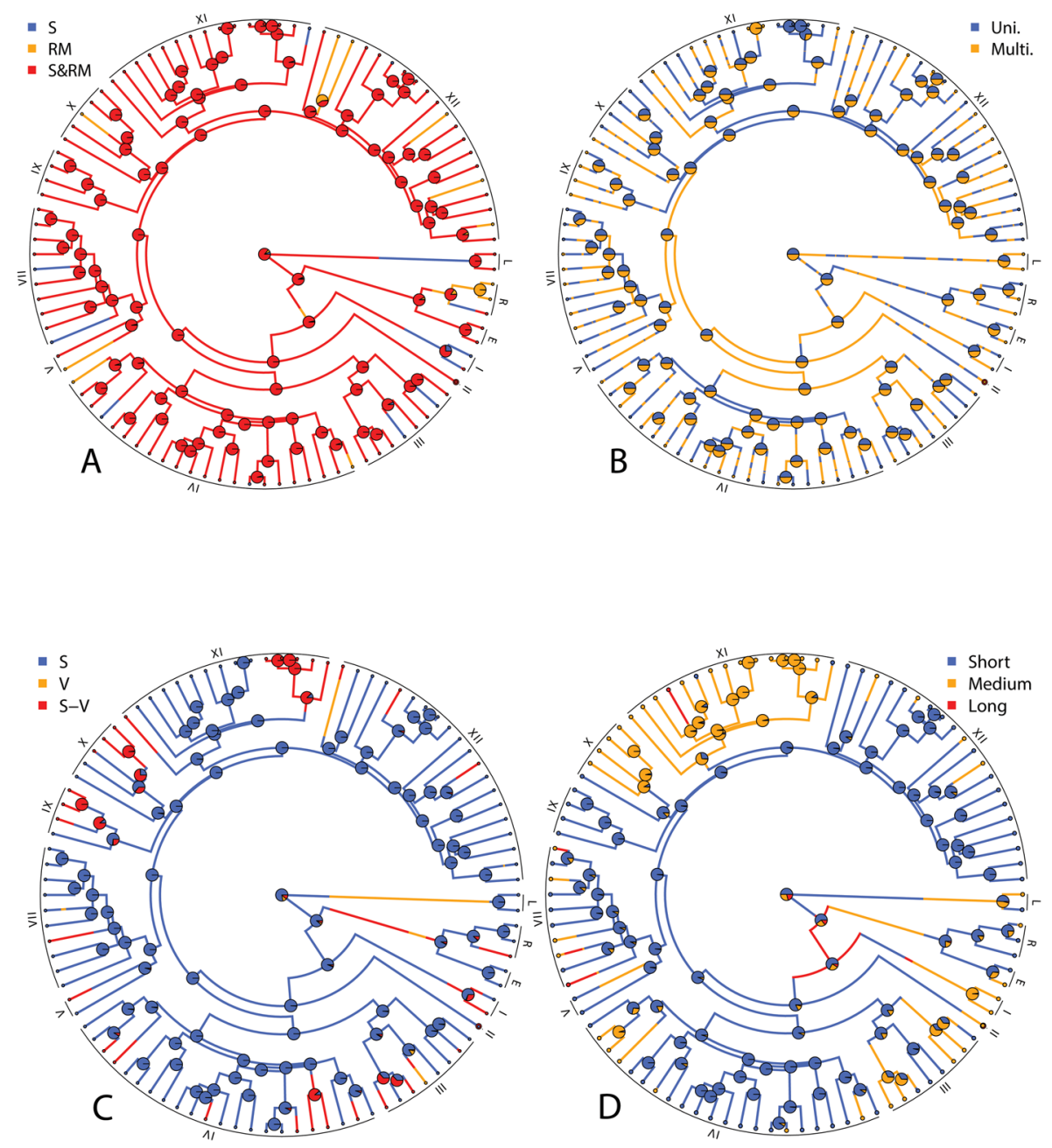

Figure A2. Ancestral state reconstructions of selected wood anatomical characters from stochastic character mapping analyses. (A) Vessel grouping (predominantly solitary, predominantly in radial multiples, solitary and in radial multiple). (B) Ray width (predominantly uniseriate, uniseriate, and multiseriate). (C) Paratracheal parenchyma (scanty, scanty to vasicentric, and vasicentric). (D) Uniseriate rays height (short, medium, and long).

Lissocarpa (based on L. bentami Tw366r7 and L. guianensis Tw23381)

Growth ring boundaries absent. Wood diffuse-porous. Tangential diameter of vessels (40)-8o-11o-(180) $\mu \mathrm{m}$, vessel elements (450)-740-1150-(1450) $\mu \mathrm{m}$ long. Vessels (7)-10-15$(22) / \mathrm{mm}^{2}$, usually in radial multiples of $2-4$ (Fig. AlD), less frequently solitary or in vessel clusters of $3-7$. Vessel outline circular. Vessel perforation plates usually simple, sporadically scalariform with up to 30 bars (Fig. A1E). Intervessel pits alternate to opposite but 


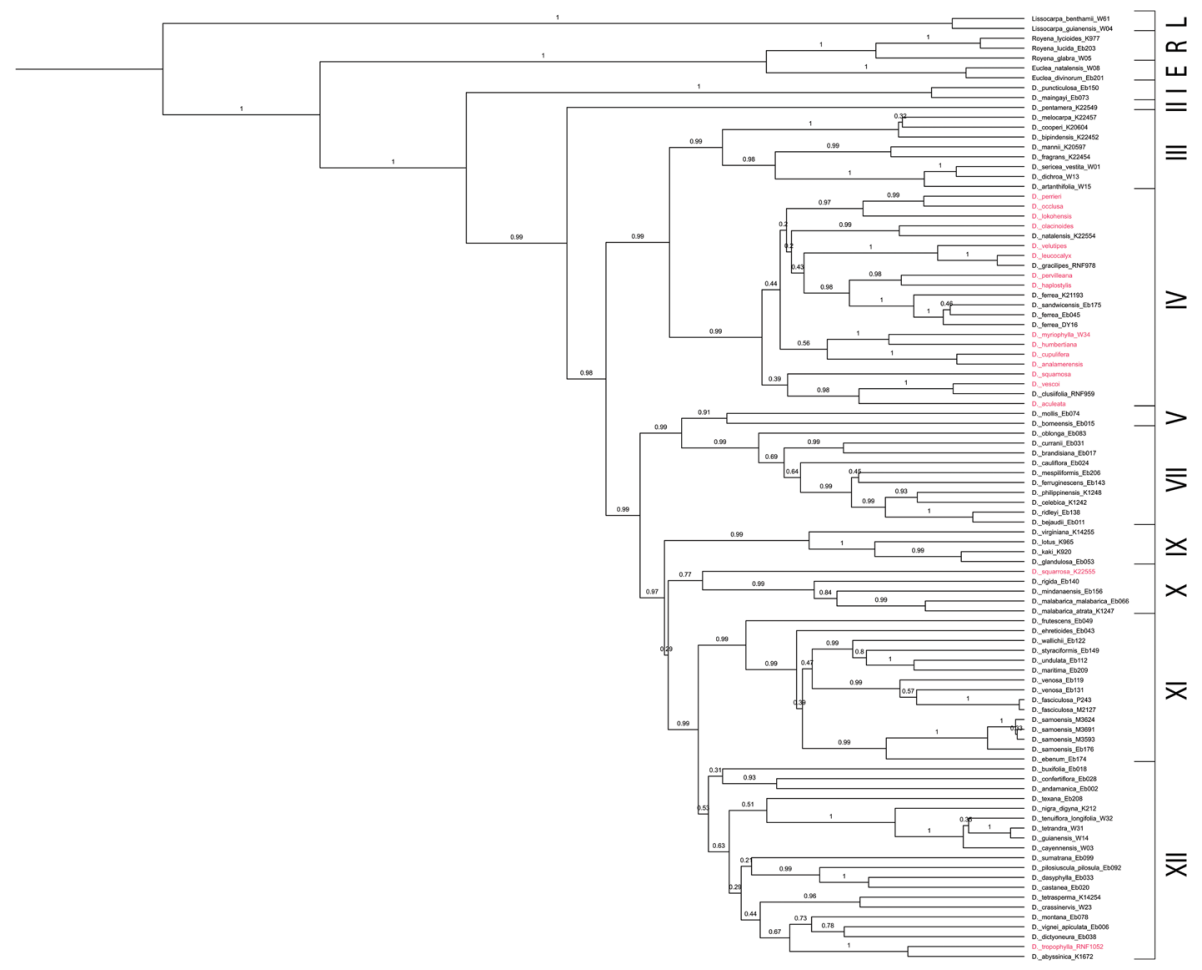

Figure A3. Phylogenetic tree resulting from Bayesian inference analyses of data from four markers $(r b c L, a t p B, t r n S-G$, and $m a t K$-trnK), with posterior probabilities shown above branches. The taxa from Madagascar are shown in red.

Table A2.

DNA sequence alignment statistics of four plastid regions analysed with BEAST.

\begin{tabular}{lccccccc}
\hline $\begin{array}{l}\text { Plastid DNA } \\
\text { region }\end{array}$ & $\begin{array}{c}\text { Sequence } \\
\text { length }\end{array}$ & $\begin{array}{c}\text { Min } \\
\text { sequence } \\
\text { length }\end{array}$ & $\begin{array}{c}\text { Max } \\
\text { sequence } \\
\text { length }\end{array}$ & $\begin{array}{c}\text { Pairwise } \\
\text { identity } \\
(\%)\end{array}$ & $\begin{array}{c}\text { Identical } \\
\text { sites (\%) }\end{array}$ & $\begin{array}{c}\text { GC (\%) } \\
\text { Best model } \\
\text { (AIC) }\end{array}$ \\
\hline rbcL & 1435 & 1321 & 1434 & $99 \cdot 3$ & 88.9 & 42.6 & TIM $+\mathrm{I}+\mathrm{G}$ \\
matK-trnK & 1516 & 1354 & 1483 & 98.3 & 62.5 & 43.1 & TVM+I+G \\
trnS-trnG & 2602 & $235^{2}$ & 2479 & 97.9 & 67.3 & 33.2 & TVM+I+G \\
\hline
\end{tabular}

the alternate type often dominates, $4^{-6} \mu \mathrm{m}$ in horizontal diameter. Vessel-ray pits alternate to opposite 4-6 $\mu \mathrm{m}$ in horizontal diameter. Tracheids absent. Non-septate fibres with simple to minutely bordered pits concentrated in radial walls, thick- to very thick-walled, (1500)-1850-2220-(2550) $\mu \mathrm{m}$ long. Axial parenchyma in bands of 1 to 2 cells wide, paratracheal parenchyma scanty, $2-4$ cells per strand. Uniseriate rays always present but less 
Table A3.

Diospyros/Euclea fossil calibration point priors based on a recently described pollen fossil treated as a minimum age constraint (56 Mya) for the split between Diospyros and Euclea (Linan et al., 2019).

\begin{tabular}{lc}
\hline Distribution & log-normal \\
\hline Mean & 1.5 \\
Standard & 0.7 \\
deviation & \\
Offset & 56 \\
\hline
\end{tabular}

Table A4.

Molecular clock priors for ucld.stdev analyses.

\begin{tabular}{lcll}
\hline ucld.stdev & & ucld.mean \\
\hline Distribution & log-normal & diffuse gamma & \\
Mean (in real & 0.9 & Alpha & 0.001 \\
space) & 1 & Beta & 1000 \\
$\begin{array}{l}\text { Standard } \\
\text { deviation }\end{array}$ & & & \\
Initial value & 0.5 & 1 & \\
\hline
\end{tabular}

frequent than multiseriate rays (Fig. AiF), (200)-270-570-(1050) $\mu \mathrm{m}$ high, consisting of procumbent or square cells, $2-4$ rays $/ \mathrm{mm}$. Multiseriate rays $2-3^{-s e r i a t e},\left(55^{\circ}\right)-950-1410-$ (2300) $\mu \mathrm{m}$ high, $5^{-10}$ rays $/ \mathrm{mm}$, consisting of procumbent body ray cells, and $1-4$ rows of upright marginal ray cells. Sheath cells absent. No mineral inclusion observed. 


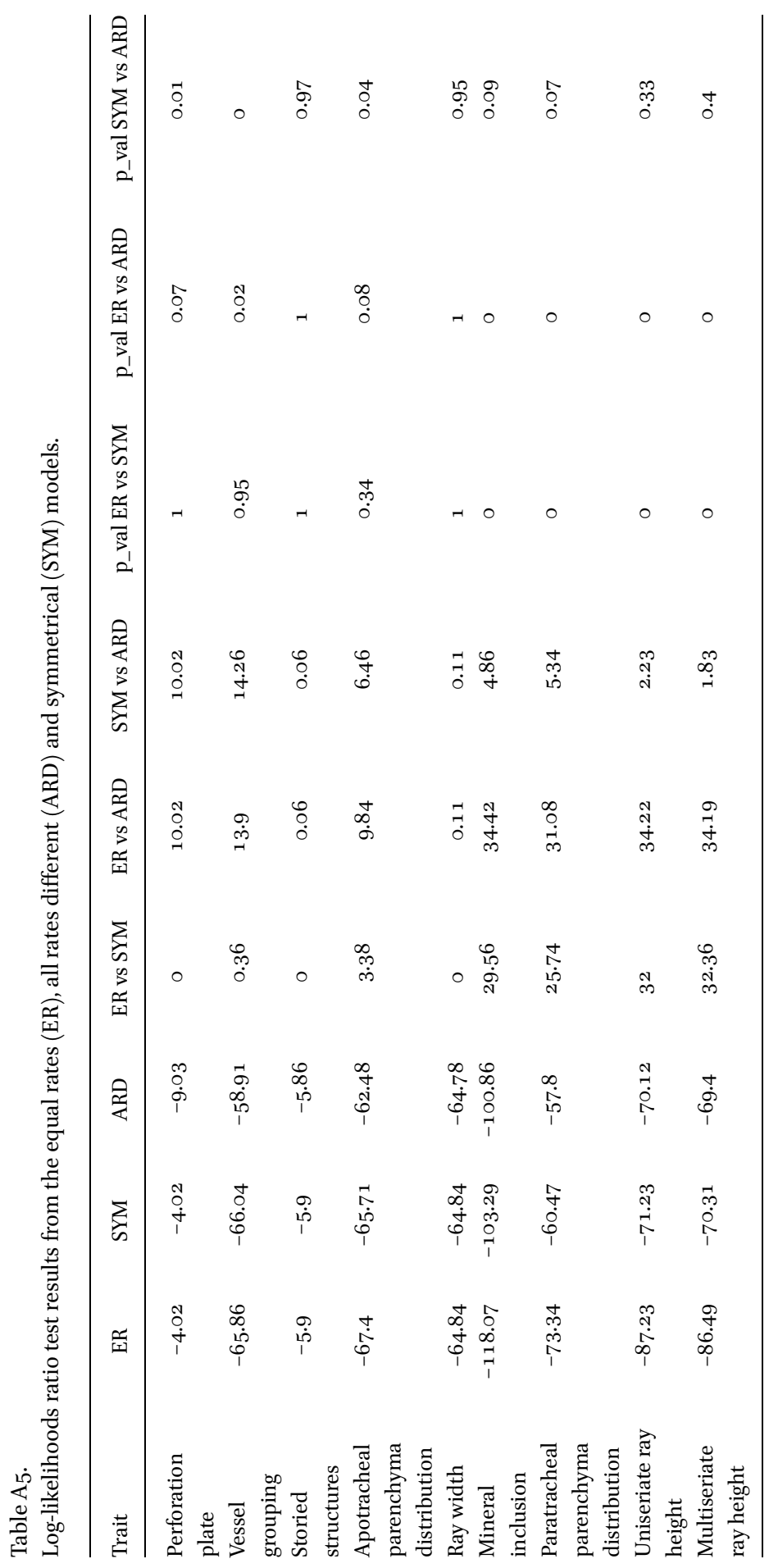




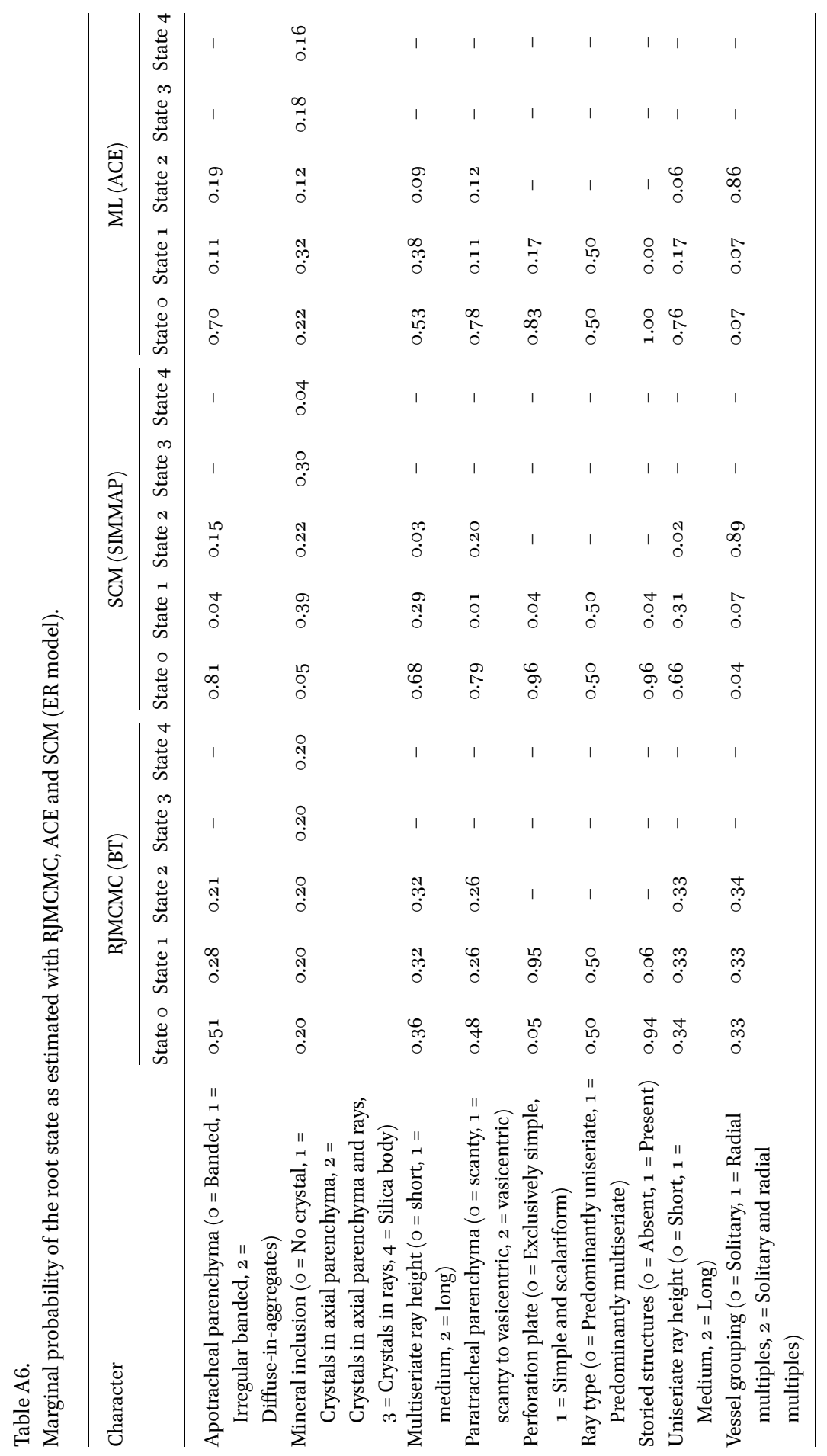

